\title{
ARTICLE
}

\section{ILLIBERAL LAW IN AMERICAN COURTS}

\author{
MARK JIA ${ }^{\dagger}$
}

American courts are at times required to interpret the laws of authoritarian countries. Though such cases are increasingly common, they remain-even today-a poorly understood feature of modern adjudication. This Article seeks to fill that gap: first by describing the scope and scale of American judicial engagement with authoritarian legal systems, second by spelling out the interpretive challenges posed by authoritarian laws, and third by building out a framework and vocabulary for analyzing judicial responses to these challenges.

The laws of authoritarian countries raise novel questions of legal construction. Such questions stem from a gap, mostly real but sometimes imagined, between our own local assumptions about law and certain "nonconforming" features of authoritarianism: sham laws, unwritten laws, party laws, politicized courts, and bifurcated legal systems. Judicial responses to these challenges fall along a familiar spectrum. Some methods have been more formalist, stressing strict correspondences. Others have been more functionalist, embracing jurisprudential difference. The optimal approach may be one in which judges tailor method to context, balancing an open-minded pluralism against minimal but irreducible principles of legality.

INTRODUCTION 1686

I. JUDICIAL ENCOUNTERS WITH FOREIGN AUTHORITARIAN LAW .1691

A. Defining Authoritarian Law 1692

B. Global Trends 1694

† J.D., Harvard Law School; M.Phil., University of Oxford; A.B., Princeton University. For generous conversation and feedback, I am indebted to William Alford, Cole Carter, Habin Chung, Donald Clarke, Jerome Cohen, Noah Feldman, Martin Flaherty, Jonathan Gould, Xiaoqian Hu, Wei Jia, Randall Kennedy, Yena Lee, Margaret Lewis, Benjamin Liebman, Lawrence Liu, John Manning, Stephen Sachs, Geoffrey Shaw, Yueduan Wang, and Mark Wu. Thanks also to Harvard Law School's East Asian Legal Studies program for supporting me during research for this Article. Finally, I am grateful to the thoughtful and careful editors at the University of Pennsylvania Law Review. 
1. Cross-Country Comparisons...............................................1694

2. Judicial Encounters with Chinese Law ..............................1699

C. Application of Foreign Law ........................................................ 1704

II. THE Distinct ChaLlenge OF ILLIBERAL LAW ......................1706

A. The Modernist Paradigm of Foreign Law .....................................1707

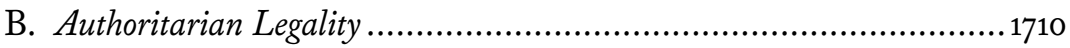

1. The Logic of Authoritarian Legality ...................................1710

2. Departures from "Modernism" ........................................... 1713

a. "Sham" Laws ......................................................... 1713

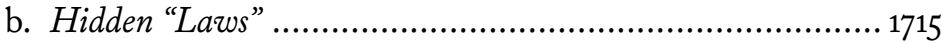

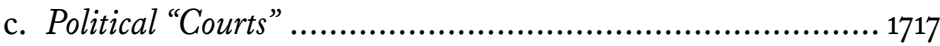

3. Bifurcated Legal Systems ...................................................1719

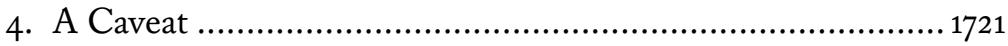

C. Antiauthoritarian Bias ............................................................1722

III. FORMAL AND FUNCTIONAL APPROACHES TO



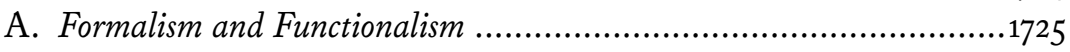

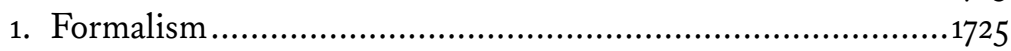

2. Functionalism .......................................................... 1726

3. Leading Cases: The Chinese Export Cases............................1727

a. The Vitamins Case-A Formalist Approach ....................... 1728

b. The Magnesite Case-A Functionalist Approach ................. 1729

c. Comparing the Compulsion Cases ..................................... 1731

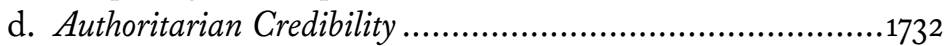

B. Formal and Functional Approaches Compared.............................. 1734

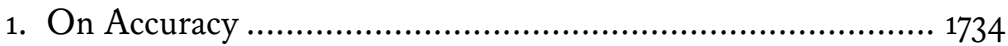

a. Qualifying the Predictive Rule ........................................ 1736

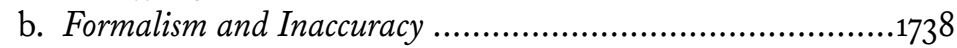

2. Efficiency and Cost ....................................................... 1740

3. Expressivity and Comity ................................................. 1741

C. Future Directions ................................................................1742

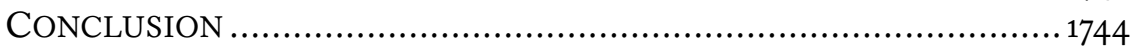

\section{INTRODUCTION}

American law has long defined itself in relation to authoritarian law. ${ }^{1}$ It is custom, almost ritual, for jurists to invoke such law as our opposite. The Fourth Amendment is a "bulwark against police practices . . . in totalitarian regimes." 2 The writ of habeas corpus separates "our democracy" from

1 For a working definition of "authoritarianism," see infra Section I.A.

2 California v. Acevedo, 500 U.S. 565, 586 (1991) (Stevens, J., dissenting). 
"totalitarian governments." 3 The First Amendment must be read in light of "how relentless authoritarian regimes are in their attempts to stifle free speech." 4 To invoke authoritarian legality is to remind us what we are not, and in so doing, keep us moored to who we think we are. ${ }^{5}$

In a more mundane sense, however, the laws of authoritarian nations are who we are-or at least, what we do. Modern doctrines of conflicts and procedure place American judges into frequent contact with the laws of authoritarian countries. Sometimes they must interpret such laws. ${ }^{6}$ Other times they must decide whether the foreign legal system is fair. ${ }^{7}$ These encounters bring authoritarian laws down to earth, where they are treated not as rhetorical foil but, presumptively, as law, to be interpreted or assessed to the best of a court's ability.

For an unacquainted jurist, such laws can appear at once familiar but strange, accessible yet elusive. Consider one example. Authoritarian legal systems can contain documents that present as "laws" but are not practically enforced. In such systems, there can exist other norms or prescripts that lack the traditional hallmarks of legality but nonetheless bind with the force of law. Where should judges locate law when the rules as written are not the norms that bind? Do they observe formality and interpret a "law," even a constitution, that local courts would not dare apply? Or do they apply other prescripts, even if they are unpublished, unwritten, or in other ways so un-law-like as to offend basic legal sensibilities? Judges are not political scientists, or philosophers, or

3 Brown v. Allen, 344 U.S. 443, 512 (1953).

4 Nat'l Inst. of Family \& Life Advocates v. Becerra, 138 S. Ct. 2361, 2379 (2018) (Kennedy, J., concurring).

5 Of course, the United States does not perfectly embody liberal democratic ideals; that has not been true historically-slavery and restrictions on the franchise are but the starkest of many examples-and it is not true today. Indeed, recent political events have led some scholars to assess the susceptibility of American institutions to authoritarian backsliding. See generally CASS R. SunSTEIN, CAN IT HAPPEN HERE?: AUTHORITARIANISM IN AMERICA (2018); Aziz Huq \& Tom Ginsburg, How to Lose a Constitutional Democracy, 65 UCLA L. REV. 78 (2018); David Pozen \& Josh Chafetz, How Constitutional Norms Break Down, 65 UCLA L. REV. 1430 (2018).

6 See, e.g., Itar-Tass Russian News Agency v. Russian Kurier Inc., 153 F.3d 82, $85-86$ (2d Cir. 1998) (Russian Copyright Law); Forzley v. AVCO Corp. Elec. Div., 826 F.2d 974, 977 (11th Cir. 1987) (Saudi Labor Law); Villoldo v. Castro Ruz, 113 F. Supp. 3d 435, 439 (D. Mass. 2015) (Cuban Law Nos. 567 and 568); Morris v. United States, No. 11-0926, 2014 WL 6982527, at * ${ }^{15}$ (M.D. Ala. Dec. 9, 2014) (Vietnam's Marriage and Family Law); United States v. Xu, No. 02-0674, 2008 WL 1315632, at *4-5 (D. Nev. Apr. 10, 2008) (Criminal Law of the People's Republic of China); Alosio v. Iranian Shipping Lines, S.A., 426 F. Supp. 687, 688 (S.D.N.Y. 1976) (Commercial Code of Iran); In re Estate of Larkin, 416 P.2d 473, 477 (Cal. 1966) (Soviet Civil Code).

7 See, e.g., Bridgeway Corp. v. Citibank, 45 F. Supp. 2d 276, 287 (S.D.N.Y. 1999) (noting that Liberian "justices and judges . . . were subject to political and social influence"); Canadian Overseas Ores, Ltd. v. Compania de Acero del Pacifico S.A., 528 F. Supp. 1337, 1342-43 (S.D.N.Y. 1982) (noting "serious questions about the independence of the Chilean judiciary vis a vis the military junta currently in power"). 
comparativists. Nor should they be. But in such cases they must arrive at an answer. How have they done so? And how ought they do so going forward?

This Article analyzes the interpretive problems posed by authoritarian laws in American courts. Part I describes the state of authoritarian law adjudication today and in the recent past, cataloging the relevant countries, cases, and doctrines. Part II illustrates how, in theory and in practice, autocratic legal systems can present interpretive challenges distinct from those associated with foreign law generally. Part III identifies two methods, formalism and functionalism, that summarize common judicial approaches to authoritarian law. These methodological choices implicate important tradeoffs between accuracy and efficiency, comity and expressivity, requiring judges to balance competing and at times irreconcilable duties inherent in the judicial role. The Article closes with a few modest suggestions for how judges can better manage such challenges.

The last scholar to address "illiberal" law adjudication did so more than a quarter-century ago. 8 In proposing a "liberal internationalist model of transnational legal relations,"9 Anne-Marie Slaughter discussed why American courts might view the laws of illiberal states as "beyond law": ideological conflict, the "shadow" of military conflict, and "the difficulty of judicial dialogue."10 If liberal courts applied illiberal law as "law," Slaughter feared, they risked "validating it according to liberal principles." ${ }^{11}$ Better, she concluded, to

8 The literature on foreign law adjudication is more voluminous. See generally, e.g., Gregory S. Alexander, The Application and Avoidance of Foreign Law in the Law of Conflicts: Variations on a Theme of Alexander Nekam, 70 NW. L. REV. 602 (1976); John R. Brown, 44.1 Ways to Prove Foreign Law, 9 MAR. LAW. 179 (1984); Roger M. Michalski, Pleading and Proving Foreign Law in the Age of Plausibility Pleading, 59 BUFF. L. REV. 1207 (2011); Arthur R. Miller, Federal Rule 44.1 and the "Fact" Approach to Determining Foreign Law: Death Knell for a Die-Hard Doctrine, 65 MiCH. L. REV. 613 (1967); Roger J. Miner, The Reception of Foreign Law in the U.S. Federal Courts, 43 AM. J. COMP. L. 581 (1995); Arthur Nussbaum, The Problem of Proving Foreign Law, 50 YALE L.J. 1018 (1941); Milton Pollack, Proof of Foreign Law, 26 AM. J. COMP. L. 470 (1978); Marcus S. Quintanilla \& Christopher A. Whytock, The New Multipolarity in Transnational Litigation: Foreign Courts, Foreign Judgments, and Foreign Law, 18 SW. J. INT'L L. 31 (2011); Matthew J. Wilson, Demystifying the Determination of Foreign Law in U.S. Courts: Opening the Door to a Greater Global Understanding, 46 WAKE FOREST L. REV. 887 (2011). For a survey of foreign law interpretation in twenty-nine countries, see generally YUKO NISHITANI, TREATMENT OF FOREIGN LAW-DYNAMICS TOWARDS CONVERGENCE? (2017).

9 Anne-Marie Burley, Law Among Liberal States: Liberal Internationalism and the Act of State Doctrine, 92 COLUM. L. REV. 1907, 1909 (1992) (internal quotation marks omitted) [hereinafter Slaughter]. Burley currently goes by the last name Slaughter.

$10 \mathrm{Id}$. at $1920-22$.

$11 \mathrm{Id}$. at 1911. 
avoid applying illiberal laws in certain settings and thereby mark such laws as outside a "zone of legitimate difference."12

Slaughter's work is best read in the context of its time. Three years earlier, Francis Fukuyama had asserted that the world was converging towards "the end of history . . . [,] the universalization of Western liberal democracy as the final form of human government." 13 Writing in a similar tradition, Slaughter envisaged a world in which dense legal linkages connected liberal nations with one another, excluding illiberal nations until they too joined in the "emerging political consensus on basic rights under law."14 Treating illiberal law as lacking legitimacy was, for Slaughter, a means to promote "progressive change."15

The world has changed since the end of the Cold War, and not always in ways liberal internationalists have predicted. While some countries have liberalized, in other places authoritarianism has endured, even strengthened,16 and liberal democracy has begun to backslide. ${ }^{17}$ Democracy export, once a "key

12 Id. at 1919 (internal quotation marks omitted); see also id. at 1913 (suggesting courts should "reinterpret 'deference' to nonliberal sovereigns as the ostracism of an outlaw").

13 Francis Fukuyama, The End of History?, NAT'L INT., Summer 1989, at 3, 3.

14 Slaughter, supra note 9, at 1913, 1917-20.

$15 I d$. at 1987. Slaughter's vision was "premised on the desirability of expanding the zone of liberal states" to foster conditions for a Neo-Kantian peace. Id. Today, of course, it is not practical or accurate (if it ever was), to divide the world into liberal countries within a "zone of law," and illiberal countries without. Harold Koh has argued that a state's liberal identity is not "exogenously or permanently given," and that illiberal states quite plainly "do law" with one another, particularly in international commercial law. Harold Koh, Why Do Nations Obey International Law?, 106 YALE L.J. 2599, 2650 (1997); see also José Alvarez, Do Liberal States Behave Better? A Critique of Slaughter's Liberal Theory, 12 EUR. J. INT'L L. 183, 192-210 (2001) (doubting liberal theory's liberal/illiberal distinction).

16 See, e.g., Mathew Burrows, The Long View on Authoritarianism's Second Wind, in IS AUTHORITARIANISM STAGING A COMEBACK? 3, 4 (Mathew Burrows \& Maria J. Stephan eds., 2015) (describing a "wall of resistance" to democracy in China, Eurasia, and most of the Middle East); Larry Diamond, Marc F. Plattner \& Christopher Walker, Introduction to AUTHORITARIANISM GOES Global: THe Challenge to DEMOCRACY 3, 4 (Larry Diamond, Marc F. Plattner \& Christopher Walker eds., 2016) (naming an "authoritarian surge" led by China, Russia, Saudi Arabia, Iran, and Venezuela as one of three notable trends following the Cold War).

17 Democratic expansion between the mid-1970s and early 1990s is often referred to as the "Third Wave" of democratization. Samuel P. Huntington, Democracy's Third Wave, J. DEMOCRACY, Spring 1991, at 12, 12. Since 1995, however, the progress of democratization "began to slow, and only modest gains were achieved in the following decade." Marc F. Plattner, Is Democracy in Decline?, J. DEMOCRACY, Jan. 2015, at 5, 7. Even more recent trend lines suggest that the "Third Wave" of democracy has "peaked." Tom Ginsburg \& Aziz Huq, How We Lost Constitutional Democracy, in CAN IT HAPPEN HERE? AUTHORITARIANISM IN AMERICA 135, 141 (Cass R. Sunstein ed., 2018). Political scientists have debated the extent of democratic retreat or backsliding in recent years. See, e.g., LARRY Diamond \& MARC F. PlatTNER, DEMOCRACY IN DECLINE? (2015); JOSHUA KURLANTZICK, DEMOCRACY IN RETREAT: THE REVOLT OF THE MIDDLE ClASS 8-9 (2013) (discussing how democracy ratings for East European countries have fallen in recent years); Valeriya Mechkova, Anna Lührmann \& Staffan I. Lindberg, How Much Democratic Backsliding?, J. DEMOCRACY, Oct. 2017, at 162, 162-64 ("The average level of democracy in the world has slipped back to where it was before the year 2000."). Other scholars have expressed a similar "concern with the health of constitutional democracies." Mark A. Graber, Sanford Levinson \& Mark Tushnet, Introduction to CONSTITUTIONAL 
organizing principle of U.S. foreign policy,"18 has largely fallen by the wayside..$^{19}$ Meanwhile, the economic, political, and cultural linkages between liberal and illiberal countries have only grown. American legal actors are now deeply enmeshed in the structures, institutions, and laws of autocratic countries. 20 Authoritarianism has evolved too. In Russia it has become less ideological.21 In China it has become in some ways more consultative. ${ }^{22}$ We now speak of

DEMOCRACY IN CRISIS? 1, 2 (Mark A. Graber, Sanford Levinson \& Mark Tushnet eds., 2018); see also David S. Law, Alternatives to Liberal Constitutional Democracy, 77 MD. L. REV. 223, 224-25 (2017) (noting that "[r]eflexive allegiance to constitutional democracy has not been the case in Latin America . . . and it certainly cannot be assumed in Asia"). Still others have sought to explain liberalism's declining appeal. See, e.g., PATRICK J. DENEEN, WHY LIBERALISM FAILED 3-6 (2018).

18 Thomas CARothers, Aiding DemOCRACY ABroAD: THE LEARNing CURVE 3 (1999).

19 "U.S. democracy high policy has reached its lowest ebb of at least the past forty years." Thomas Carothers \& Frances Z. Brown, Can U.S. Democracy Policy Survive Trump?, CARNEGIE ENDOWMENT FOR INT'L PEACE (Oct. 1, 2018), https://carnegieendowment.org/2018/10/01/canu.s.-democracy-policy-survive-trump-pub-77381 [https://perma.cc/L4LJ-5N75]; cf. William P. Alford, Exporting "The Pursuit of Happiness," 113 HARV. L. REV. 1677, 1681 (2000) (reviewing THOMAS CAROTHERS, AIDING DEMOCRACY ABROAD: THE LEARNING CURVE (1999)) (calling for humility and introspection in approaching democracy export).

20 See, e.g., ARCH PUDDINGTON, BREAKING DOWN DEMOCRACY: GOALS, STRATEGIES, AND METHODS OF MODERN AUTHORITARIANS 2 (2017), https://freedomhouse.org/sites/default/files/June 2017_FH_Report_Breaking_Down_Democracy.pdf [https://perma.cc/8WP7-PYRY] (describing how "autocracies" such as China, Russia, Kazakhstan, Azerbaijan, Turkey, and Ethiopia are increasingly employing "political consultants and lobbyists from democratic countries to represent the[ir] interests"). Outbound investment flows have brought companies in authoritarian countries into close contact with American regulatory regimes. See generally Ji LI, THE CLASH OF CAPITALISMS?: CHINESE COMPANIES IN THE UNITED STATES (2018). Relatedly, statutes like the Foreign Corrupt Practices Act have enmeshed American laws and lawyers with institutions and practices in countries like Russia, China, and Saudi Arabia. See generally, e.g., Matthew S. Erie, Anticorruption as Transnational Law: The Foreign Corrupt Practices Act, PRC Law, and Party Rules in China, 67 AM. J. COMP. L. 233 (2019). Global governance reforms have also required American lawyers to be more attentive to state-centered economic structures found in places like China. See generally Mark Wu, The "China, Inc." Challenge to Global Trade Governance, 57 HARV. INT'L. L.J. 261 (2016). Closer to home, many American universities have struggled with issues arising from partnerships with institutions in authoritarian countries. See Martin S. Flaherty, "But for Wuhan?": Do Law Schools Operating in Authoritarian Regimes Have Human Rights Obligations?, 5 DREXEL L. REV. 297, 302-08 (2013).

21 See Sam G. McFarland, Vladimir S. Ageyev \& Marina A. Abalakina-Paap, Authoritarianism in the Former Soviet Union, 63 J. PERSONALITY \& SOC. PSYCHOL. 1004, 1008 (1992) (concluding that "the rapid demise of communism has deprived Soviet authoritarianism of its ideology"). But recent years have seen a rise in conservative nationalism in Russia

22 See Andrew J. Nathan, Authoritarian Resilience, J. DEMOCRACY, Jan. 2003, at 6, 6; Rory Truex, Consultative Authoritarianism and its Limits, 50 COMP. POL. STUD. 329, 330 (2017) (describing the adoption of public opinion polling, participatory budgeting, and other "input institutions" in Chinese governance); Steve Tsang, Consultative Leninism: China's New Political Framework, 18 J. CONTEMP. CHINA 865, 866 (2009) (describing Chinese governance as "a system that blends together the Leninist instrument of control with innovations from other sources"). See generally MARTIN K. DIMITROV, WHY COMMUNISM DID NOT COLLAPSE: UNDERSTANDING AUTHORITARIAN RESILIENCE IN ASIA AND EUROPE (2013). In other areas, however, Chinese rule has become more centralized and personalistic. See Susan L. Shirk, China in Xi's "New Era": The Return to Personalistic Rule, J. DEMOCRACY, Apr. 2018, at 22, 23. 
intermediate regime types, with new labels such as "illiberal democracy" or "competitive authoritarianism" conveying the many colors and hues of modern illiberal governance. ${ }^{23}$

These changes introduce both new complexities and a renewed urgency to the challenges posed by authoritarian laws in U.S. courts. Such cases have become fixtures on the dockets of many district courts, especially in commercial centers. In a recent Term, the Supreme Court grappled with how much deference to accord an interpretation of Chinese law submitted by the Chinese government. ${ }^{24}$ "Given the world's many and diverse legal systems," the Court concluded, the appropriate level of deference ought to account for, among other things, "the transparency of the foreign legal system." ${ }^{25}$ How should courts regard legal sources from authoritarian nations? How should judges deal with legal systems that appear "modern" in some sectors but "aberrational" in others? Questions such as these remain either unaddressed or undertheorized since Slaughter formulated a version of the problem decades earlier. This Article takes up the inquiry anew, at a time in which the end of history is nowhere in sight.

\section{JUDICIAL ENCOUNTERS WITH FOREIGN AUTHORITARIAN LAW}

I begin with a thick account of authoritarian law adjudication, identifying the relevant countries, courts, cases, sources, and doctrines. American judges, I find, have engaged more deeply with foreign illiberal law than many would expect. While this may irk those hostile to foreign law in general, it comports with what scholars of transnational litigation have suggested for some time: globalization has created innumerable touch-points between disparate legal orders, and despite a parochialism in American law, ${ }^{26}$ judicial encounters with the laws of autocratic countries are increasingly unavoidable.

23 See, e.g., Steven Levitsky \& Lucan A. Way, The Rise of Competitive Authoritarianism, J. DEMOCRACY, Apr. 2002, 51, 52-54 (defining "competitive authoritarianism" as a regime in which elections serve as "the principal means of obtaining and exercising political authority," but in which incumbents frequently hold on to power though the violation of democratic rules); Fareed Zakaria, The Rise of Illiberal Democracy, FOREIGN AFF., Nov.-Dec. 1997, at 22, 22 (coining the term "illiberal democracy"). A parallel phenomenon has developed with respect to constitutionalism. See, e.g., Mark Tushnet, Authoritarian Constitutionalism, 100 CORNELL L. REV. 391, 394 (2015) (developing the concept of "authoritarian constitutionalism"); see also David S. Law \& Mila Versteeg, Constitutional Variation Among Strains of Authoritarianism, in CONSTITUTIONS IN AUTHORITARIAN REGIMES 165, 181-87 (Tom Ginsburg \& Alberto Simpser eds., 2014) (describing the use of "sham constitutions" by different types of authoritative regimes).

24 Animal Sci. Prods., Inc. v. Hebei Welcome Pharm. Co., 138 S. Ct. 1865, 1873-74 (2018).

$25 \mathrm{Id}$. at 1873.

26 See Pamela Bookman, Litigation Isolationism, 67 STAN. L. REV. 1081, 1081, 1088-1108 (2015) (describing American courts' "studied avoidance" of transnational litigation); Maggie Gardner, Parochial Procedure, 69 STAN. L. REV. 941, 944 \& n.1 (2017) (expressing concern that "the federal courts' procedural decisions are problematically biased in favor of U.S. parties and U.S. law"). 


\section{A. Defining Authoritarian Law}

Before turning to description, it may be helpful to specify what I mean and do not mean by "authoritarian law." To start, I do not mean laws that are substantively authoritarian, e.g., those that repress civil and political rights, though such laws are presumably more prevalent in authoritarian countries. Rather, I am interested in all rules that purport to be laws in authoritarian countries. 27

What makes a country authoritarian? As I see it, authoritarianism refers to (1) a distinct form of governance (2) defined not merely by the absence of free elections, (3) but by a set of affirmative practices that maintain unfettered rule through undermining institutions and processes that hold ultimate decisionmakers accountable.

My first proposition-that authoritarianism is a distinct form of governance-may seem obvious. It warrants discussion though because authoritarianism has in other corners of the literature been regarded merely as a residual category, encapsulating all that is not democracy. ${ }^{28}$ This view is sensible if one sees authoritarianism as an aberration, which may appeal to scholars of democratic transition. ${ }^{29}$ But for students of authoritarianism specifically, the definition leaves something to be desired. For one, it treats authoritarianism as a container concept that includes other regime types to which "authoritarian" would be an ill-fitting label, such as the failed state. ${ }^{30} \mathrm{It}$ also ignores the ways in which authoritarianism is itself a distinct mode of "organizing political life," with consequences for a number of governance outcomes, 31 including the nature of law and legal institutions.

27 Courts may refuse to apply foreign laws, including those that are substantively authoritarian, if they contravene the public policy of the forum. RESTATEMENT (SECOND) OF CONFLICT OF LAWS § 90 (AM. LAW INST. 1971). The "public policy exception," however, is not commonly invoked. As Justice Cardozo explained, not "every solution of a problem is wrong because we deal with it otherwise at home." Loucks v. Standard Oil Co., 120 N.E. 198, 201-02 (N.Y. 1918). But see EM Ltd. v. Republic of Argentina, 389 F. App'x 38 (2d Cir. 2010).

28 See José Antonio Cheibub, Jennifer Gandhi \& James Raymond Vreeland, Democracy and Dictatorship Revisited, PUB. CHOICE, Apr. 2010, at 67, 83 (stating that autocracies have been treated "as a residual category for much time-everything that democracy is not").

29 The "umbrella" assumption of the transition paradigm is that "any country moving away from dictatorial rule can be considered a country in transition toward democracy." Thomas Carothers, The End of the Transition Paradigm, J. DEMOCRACY, Jan. 2002, at 5, 6. This assumption is not only empirically false, see id., it is also conceptually misleading.

30 Failed states are states that have "lo[st] control over the means of violence," unable to "create peace or stability for their populations or control their territories." Rosa Ehrenreich Brooks, Failed States, or the State as Failure?, 72 U. CHI. L. REV. 1159, 1160 (2005).

31 See Cheibub et al., supra note 28 , at 83 ("[D]ictatorships increasingly are recognized as a political regime encompassing different ways of organizing political life that have consequences for understanding policies, outcomes, and the stability of authoritarianism itself."). 
For similar reasons, I reject a minimalist definition of authoritarianism as any system that lacks free and competitive elections. ${ }^{32} \mathrm{~A}$ lack of genuine popular contestation for political power is characteristic of all authoritarian regimes. But, like authoritarianism-as-aberration, a negative Schumpeter-ian definition obscures the affirmative practices that characterize authoritarian rule. ${ }^{33}$

Put simply, authoritarianism is best understood as a regime-level commitment to a set of practices that help unfetter rule through undermining institutions that hold ultimate decisionmakers accountable. Interfering with elections, to the extent they even occur, is a key tactic within this broader arsenal of practices, but it is just one practice. Also "authoritarian" are the restrictions on expression, press freedom, governmental transparency, civil society, and judicial independence that help dislodge the ultimate decisionmaker(s) from institutionalized constraints. ${ }^{34}$

By defining authoritarianism as a system-wide commitment to certain affirmative practices, one can more easily determine whether there is anything distinctive about authoritarian law. Law, after all, is not just a tool of governance; it can also be an institution of accountability. As explained further below, the ways in which autocrats attempt to stifle, manage, and control this particular institution has significant implications for the nature of autocratic law. This definition also accords better with common usage. When analysts speak of rising authoritarianism around the world, they do not just mean that elections have become less fair. They speak too of assaults on other accountability institutions that might otherwise constrain limitless rule, including courts, civil society, and the media. 35

32 One leading study, for instance, coded a regime as "autocratic" whenever the executive attained power through "any means besides direct, reasonably fair, competitive elections." Barbara Geddes, Joseph Wright \& Erica Frantz, Autocratic Breakdown and Regime Transitions: A New Data Set, 12 PERSP. POL. 313, 317 (2014).

33 There are of course compelling methodological reasons for defining authoritarianism more thinly; dichotomous proxy-variable categorizations may be necessary in large-n studies, for example.

34 This conception of authoritarianism draws inspiration from Marlies Glasius's definition of "authoritarian practices" as "accountability sabotage." See Marlies Glasius, What Authoritarian Is . . . and Is Not: A Practice Perspective, 94 INT'L AFF. 515, 525-26 (2018). Glasius defines an "authoritarian practice" as "a pattern of actions, embedded in an organized context, sabotaging accountability to people ('the forum') over whom a political actor exerts control, or their representatives, by disabling their access to information and/or disabling their voice." Id. at 527. I do not follow her definition in full. I define authoritarianism at the regime-level; I focus not just on practices that disable information or the voice of the people, but also on other institutional checks on power, such as courts; and I stress the effectively supralegal status of the ultimate decider(s).

35 See, e.g., Brian Klaas, Trump's Authoritarian Backlash Has Already Begun, WASH. POST (Nov. 9, 2018), https://www.washingtonpost.com/news/democracy-post/wp/2018/11/og/trumps-authoritarianbacklash-has-already-begun/?utm_term=.19a2905e8ob2 [https://perma.cc/72X6-J2ST] (describing President Donald Trump's "attack on press freedom" as "dangerously authoritarian"). To be clear, an increase in "authoritarian practices" in places like the United States has not rendered America an 
None of this is to say authoritarian countries reject accountability institutions entirely. Large autocracies may rely on judges or journalists to keep local officials in line. The defining feature of authoritarianism, however, is that the ultimate decider(s) are programmatically and successfully engaged in undermining accountability processes. Authoritarianism, writes Mark Tushnet, generally requires "a single decision maker . . . whose decisions are both formally and practically unregulated by law." 36

A final note: I sometimes use the term "authoritarian" interchangeably with "illiberal." The two concepts are not coterminous. Liberalism refers to a commitment to values associated with the Enlightenment: pluralism, tolerance, and individual liberty, while authoritarianism is a mode of political organization. But authoritarian governance is fundamentally illiberal in its ordering of the state over the individual. It is that element of illiberalism that I emphasize.

\section{B. Global Trends}

\section{Cross-Country Comparisons}

To set the scene, I begin with some basic data points. How often do U.S. courts engage with the laws of specific authoritarian countries? Have encounter rates changed over time? Which courts encounter authoritarian laws most often?

I answer these questions by comparing search statistics on Westlaw. For each target country, I entered three distinct search strings into the main Westlaw Edge case database ("All State \& Federal"). In the case of Vietnam, for example, I searched: (1) Vietnam!37 /8 law; (2) Vietnam! \& 44.1; (3) Vietnam! /8 forum. The first string generates all cases within the database in which the country term appears within eight words of "law." Through trial and error, I concluded that a "/8" search tended to maximize relevant cases without yielding too many irrelevant cases. 38 The second search string generates all cases in which the

"authoritarian state," for attacks on accountability institutions have not resulted in the existence of an effectively supralegal decisionmaker in American politics.

36 Tushnet, supra note 23 , at $448 \& \mathrm{n} .296$ (2015) (acknowledging that the single decisionmaker could be a collective body).

37 The exclamation point generates searches for all instances in which the word "Vietnam" or any word that begins with "Vietnam" (such as "Vietnamese") appears. Where relevant, I used the "!” key for every country on my list: e.g., "Afghan!"; “Angola!”; "Azerbaijan!” The main exception was China, for which I instead used "China OR Chine!". Had I instead used "Chin!," I would have generated too many nonresponsive results given how often "Chin" appears as a party surname.

38 The (admittedly crude) trial and error process proceeded as follows: I examined every case in the database in which both "China OR Chine!" and "law" appeared. I then reviewed search results for various searches: e.g., "China OR Chine!" / 2 law"; "China OR Chine!" /3 law." I found that when the /? number fell below 8 , the search string would miss cases involving extensive judicial 
country term and "44.1" both appear. Federal Rule of Civil Procedure 44.1 governs determinations of foreign law. Unlike the first string, which aims to maximize relevant hits, this second string minimizes false positives. The third string generates all cases in which the country term appears within eight words of "forum." This string targets cases involving forum non conveniens, an analysis that often requires evaluation of an alternative forum's legal system.

To determine which countries qualify as "authoritarian," I consulted the POLITY IV database. POLITY scores measure regime type by "coding the authority characteristics of states." ${ }^{39}$ Individual coding scores are aggregated into a Combined POLITY Score ranging from +10 (strongly democratic) to -10 (strongly autocratic). 40 Unlike other indices that primarily measure political and civil rights, ${ }^{41}$ POLITY scores measure "authority" characteristics that somewhat better approximate the definition of "authoritarianism" adopted in this Article. One variable, for instance, looks to the degree of actual constraint on the powers of the chief executive. 42 Another variable assesses whether "significant oppositional activity is permitted outside the ranks of the regime and ruling party." 43 After making a few minor adjustments, ${ }^{44}$ I searched Westlaw for all countries that had POLITY scores between $O$ and -10 in 2016.

The approach is imperfect. Relying on a single year's POLITY scores does not account for variation over time. Chile may not have been on the 2016 autocracy list, but it certainly was under Pinochet. ${ }^{45}$ Conversely, Turkey had

engagement with Chinese law. When the /? number exceeded 8, the search generated many irrelevant hits without appreciably increasing the number of relevant hits.

39 Monty G. MARShall, TEd Robert GurR \& KeITH Jaggers, CTR. FOR SySTEMIC PEACE, Polity IV Project: Political Regime CHARACTERISTICS AND TRANSitions, $1800-$ 2017, DATASET USERS' MANUAL 1 (2018), http://www.systemicpeace.org/inscr/p4manualv2017.pdf [https://perma.cc/5GK7-LY92]. Coding variables for "autocracy" include: competitiveness of executive recruitment, openness of executive recruitment, constraints on the chief executive, regulation of participation, and competitiveness of participation. Id. at 16.

40 The calculation technically requires the calculation of two scores, an AUTOC and DEMOC score. The Combined POLITY Score is computed by subtracting the former from the latter. Id. at 16 .

41 The most prominent of these is the Freedom House score. For a discussion of the advantages and disadvantages of using Freedom House and POLITY scores as regime measures, see Cheibub et al., supra note 28 , at $74-79$.

42 See Marshall et al., supra note 39, at 24.

$43 \mathrm{Id}$. at 26.

44 The biggest adjustment was to include Russia, which the 2016 POLITY measures regard as a weak democracy rather than an autocracy. See MONTY G. MARSHALL \& GABRIELLE ELZINGAMARSHALL, CTR. FOR SYSTEMIC PEACE, GLOBAL REPORT 2017: CONFLICT, GOVERNANCE, AND STATE FRAGILITY 47 (2017), http://www.systemicpeace.org/vlibrary/GlobalReport2017.pdf [https:// perma.cc/M6TQ-UFLQ]. I included the former Soviet Union as a separate entry. I also omitted a few smaller autocracies-Chad, Jordan, Oman, and even Angola. Because these country share names with individual persons, typically lawyers or parties, Westlaw searches were unhelpfully overinclusive.

45 See CTR. FOR Systemic PEACE, POlity IV COUNTRY REPORT 2010: CHILE 1-2 (2011), http://www.systemicpeace.org/polity/Chile2010.pdf [https://perma.cc/TR 5 E-WJKP]. 
a negative POLITY score in 2016,46 but as recently as 2010, it was rated a fairly strong democracy. ${ }^{47}$ In general, though, the major countries on this list-indeed, the ones most likely to appear on U.S. dockets-have remained stably autocratic through recent decades.

The results are presented in Table 1. Each country is ranked by its composite score - the sum of the three individual search results minus any overlapping cases. 48 Though the scores lack meaning by themselves, they facilitate comparison between countries.

Table 1: Westlaw Search Hits by Country (July 23, 2019)

\begin{tabular}{lcccc} 
Country & $\begin{array}{c}\text { Total Unique } \\
\text { Search Hits }\end{array}$ & $\begin{array}{c}\text { Search Hits } \\
\text { /8 law }\end{array}$ & $\begin{array}{c}\text { Search Hits } \\
\text { \& } 44 \cdot 1\end{array}$ & $\begin{array}{c}\text { Search Hits } \\
\text { /8 forum }\end{array}$ \\
\hline \hline China & 3,960 & 3,544 & 318 & 310 \\
Turkey & 1,405 & 1,281 & 108 & 104 \\
Russia & 1,361 & 1,218 & 153 & 138 \\
Cuba & 1,182 & 1,046 & 147 & 39 \\
Iran & 933 & 708 & 126 & 188 \\
Saudi Arabia & 760 & 590 & 42 & 149 \\
Venezuela & 751 & 573 & 122 & 177 \\
Singapore & 578 & 456 & 88 & 159 \\
Vietnam & 503 & 456 & 38 & 31 \\
Egypt & 465 & 358 & 65 & 99 \\
Thailand & 410 & 375 & 28 & 27 \\
Soviet Union & 328 & 286 & 52 & 6 \\
Kuwait & 255 & 206 & 44 & 34 \\
UAE & 238 & 208 & 33 & 30 \\
Libya & 166 & 122 & 40 & 14 \\
Sudan & 157 & 100 & 54 & 13 \\
Afghanistan & 156 & 137 & 28 & 7 \\
Congo & 141 & 81 & 33 & 29 \\
& & & &
\end{tabular}

46 See MARSHALl \& ElZINGA-MARSHALL, supra note 44.

47 See CTR. FOR Systemic PEACE, POlity IV COUNTRY REPORT 2010: TURKEY 1 (2011), http://www.systemicpeace.org/polity/Turkey2010.pdf [https://perma.cc/4HJ7-MEDR]. Turkey's 2010 POLITY score was 7. Id.

48 The search string for the composite score for Vietnam would be (Vietnam! /8 law) OR (Vietnam! \& 44.1) OR (Vietnam! /8 forum). 


\begin{tabular}{lllll} 
Syria & 135 & 116 & 22 & 6 \\
Morocco & 129 & 114 & 14 & 11 \\
Laos & 120 & 100 & 18 & 4 \\
Ethiopia & 86 & 67 & 15 & 10 \\
Kazakhstan & 82 & 65 & 12 & 10 \\
Cambodia & 70 & 66 & 5 & 1 \\
Qatar & 60 & 46 & 8 & 13 \\
Yemen & 57 & 48 & 8 & 5 \\
Bahrain & 55 & 41 & 11 & 14 \\
Uganda & 40 & 34 & 6 & 3 \\
Cameroon & 38 & 31 & 3 & 11 \\
Rwanda & 34 & 32 & 2 & 0 \\
Belarus & 28 & 22 & 6 & 1 \\
North Korea & 27 & 24 & 3 & 0 \\
Turkmenistan & 27 & 26 & 1 & 2 \\
Togo & 24 & 15 & 4 & 6 \\
Eritrea & 20 & 16 & 0 & 5 \\
Azerbaijan & 19 & 7 & 7 & 6 \\
Uzbekistan & 17 & 16 & 1 & 0 \\
Equatorial & 15 & 13 & 2 & 3 \\
$\quad$ Guinea & & & & 0 \\
Mauritania & 5 & 5 & 0 & 0 \\
Swaziland & 5 & 5 & 0 & \\
Tajikistan & 3 & 2 & 1 & 0 \\
Burundi & 3 & 2 & 0 & \\
\hline
\end{tabular}

A few trends stand out. First, China tops the list in every category. That is, regardless of search string, searches for China return the most cases. Other countries with high case counts include Turkey, Russia, the Soviet Union, Cuba, Iran, Saudi Arabia, Venezuela, Singapore, Egypt, and Vietnam.

For context, consider composite search results for nonauthoritarian countries. A search of English or British law generates composite figures of over 10,00o hits. Composite searches for French law also yields over 10,00o hits, while searches for Canadian and German law yield 8139 and 8395 hits respectively. In contrast, China's composite number is 3960 . While substantially lower than the 
aforementioned countries, this figure nonetheless exceeds the composite figures for Israel (2634), Italy (2243), Japan (2350), and Australia (1387).

Even if absolute search figures are higher in France and England, rates of authoritarian law adjudication have grown significantly over time. Consider Table 2, which plots composite search hits over successive five-year periods since 1979 for three countries: China, Russia/Soviet Union (combined), and Saudi Arabia.

Table 2: Search Hits over Time - China, Russia/Soviet Union, and Saudi Arabia (July 23, 2019)

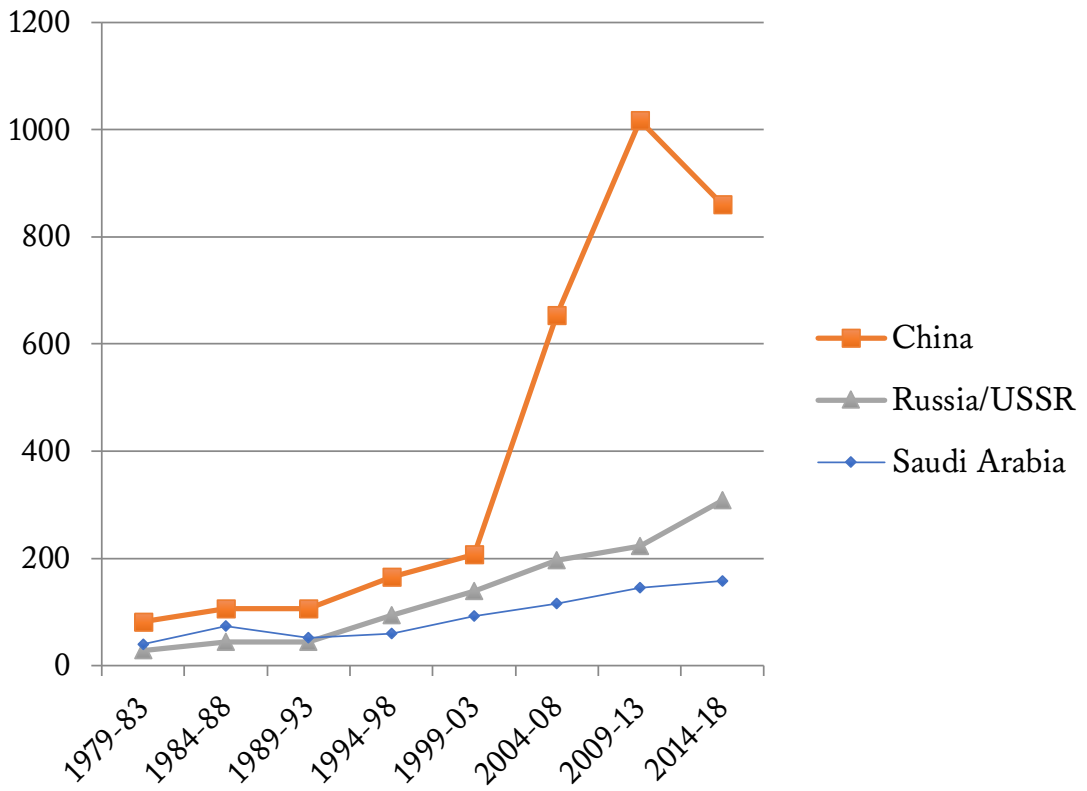

China, in particular, has had its case counts grow from less than 200 in the five-year periods before the turn of the millennium to a high of over 1000 in the five-year period beginning in 2009.

None of these results are surprising. The countries that top the lists-China, Russia, Saudi Arabia, and Turkey-tend to be significant geopolitical and economic players; they and their people have significant business relationships with American and multinational entities; and their citizens frequently travel or emigrate to the United States. These and other touchpoints set the stage for a variety of disputes that demand judicial resolution.

Search statistics alone, however, tell us little of the nature of these interactions: the laws that have been interpreted, the assessments judges have made, and the role of other actors within the interpretive process. The 
following subsection provides a more granular account of judicial touch-points with authoritarian law, focusing on the country that has led every table so far.

\section{Judicial Encounters with Chinese Law}

For most of American history, judges engaged only sporadically with Chinese law. Such laws would arise on occasion in family or immigration disputes, but without experts or special materials, judges resorted to general principles of law instead. ${ }^{49}$ So sparse was the availability of Chinese law expertise that one judge in 1928 considered U.S. immigration officials to be "experts on Chinese law and customs." 50 Writing in the 1970s, a judge tasked with construing Chinese law said he felt as if he was "operating in the dark." 51

In 1978, China began to modernize its legal system in the service of economic reform. ${ }^{52}$ What followed was a rapid increase in the economic, political, cultural, and human linkages between the United States and China. By the early 2000s, these linkages had generated a significant uptick in U.S. cases concerning Chinese law. In recent years, American courts have had to construe or assess Chinese laws governing arbitration, ${ }^{53}$ banking, ${ }^{54}$ competition, ${ }^{55}$ contracts, ${ }^{56}$

49 See, e.g., Louknitsky v. Louknitsky, 266 P.2d 910, 911 (Cal. Dist. Ct. App. 1954) ("There being no evidence concerning the applicable laws of China or of Hongkong [sic] . . . , those laws are presumed to be the same as the laws of California."); Indus. Exp. \& Imp. Corp. v. Hongkong \& Shanghai Banking Corp., 77 N.Y.S. 2d 541, 544 (Sup. Ct. 1947) (assuming that "general principles" concerning commercial transactions prevail in China); cf. Miller, supra note 8, at 635 ("Perhaps the oldest and most convenient device for bypassing the need to prove foreign law . . . is the postulate that when the principle of law at issue is 'rudimentary,' it can be presumed to subsist in all civilized jurisdictions.").

50 Tillinghast v. Chin Mon ex rel. Chin Yuen, 25 F.2d 262, 266 (1st Cir. 1928) (Anderson, J., dissenting). For many during this period, Chinese law epitomized "foreignness" in foreign law. $C f$. Goldman v. Mollen, 191 S.E. 627, 632 (Va. 1937) ("Jewish law, as such, is no more to be followed in Virginia than is Chinese law.").

51 Lau v. Kiley, 410 F. Supp. 221, 223 (S.D.N.Y. 1976).

52 See StANLEY B. LUBMAN, BiRd In A CAGE: LEGAL REFORM IN CHINA AFTER MAO 2 (1999).

53 See Apple \& Eve, LLC v. Yantai N. Andre Juice Co., 499 F. Supp. 2d 245, 250-51 (E.D.N.Y. 2009) (determining the validity of an arbitration clause under Chinese law); Slinger Mfg. Co. v. Nemak, S.A., No. 08-0656, 2008 WL 4425889, at ${ }^{*}$ (E.D. Wis. Sept. 24, 2008) (applying the Arbitration Law of the People's Republic of China).

54 See Tiffany (NJ) LLC v. Dong, No. 11-2183, 2013 WL 4046380, at * 13 (S.D.N.Y. Aug. 9, 2013) (noting concerns over contravening China's Banking Law); Wurtz v. Bank of China Ltd., 942 F. Supp. 2d 452, 463-66 (S.D.N.Y. 2013) (interpreting Chinese bank secrecy laws); Samsun Logix Corp. v. Bank of China, No. 105262/10, 2011 WL 1844061, at *6 (N.Y. Sup. Ct. May 12, 2011) (citing an expert affidavit discussing Chinese commercial bank disclosure laws).

55 See Vringo, Inc. v. ZTE Corp., Nos. 14-4988, 15-0986, 2015 WL 2380061, at *2 (S.D.N.Y. May 14,2015 ) (assessing whether article 42 of China's Anti-Monopoly Law serves as a blocking statute).

56 See Slinger $M f g$., $2008 \mathrm{WL} 4425889$, at *4 (applying "[g]eneral PRC contract law"); CPM Indus., Inc. v. Fayda Chems. \& Minerals, Inc., No. 15996, 1997 WL 770683, at *2, *8 (Del. Ch. Nov. 26, 1997) (citing an expert affidavit opining that Chinese law gave one party authority to bind another to an exclusive agreement). 
corporations, ${ }^{57}$ criminality, ${ }^{58}$ export, ${ }^{59}$ family relations, 60 foreign exchange, 61 foreign investment, 62 jurisdiction, 63 privilege, 64 procedure, 65 securities, 66 service of process, 67 state secrets, 68 tortious conduct, 69 and intellectual property. ${ }^{70}$

57 See Wang v. Beta Pharma, Inc., No. 14-01790, 2015 WL 5010713, at *7 (D. Conn. Aug. 24, 2015) (determining whether the Chinese Company Law precluded a party from providing relief); InStep Software, LLC v. InStep (Beijing) Software Co., No. 11-03947, 2012 WL 1107798, at * 3 (N.D. Ill. Mar. 29, 2012) (concluding from Chinese Company Law that a party was a "juridical person").

58 See United States v. Xu, No. 02-0674, 2008 WL 1315632, at * 5 (D. Nev. Apr. 10, 2008) (interpreting fraud-related provisions of the Chinese Criminal Law).

59 See In re Vitamin C Antitrust Litig., 810 F. Supp. 2d 522, 553-67 (E.D.N.Y. 2011) (interpreting Chinese export regulations); Animal Sci. Prods., Inc. v. China Nat'l Metals \& Mineral Imp. \& Exp. Corp., 702 F. Supp. 2d 320, 441-452 (D.N.J. 2010) (analyzing export-related working rules, notices, and measures issued by the Chinese Ministry of Commerce), vacated and remanded sub nom. Animal Sci. Prods. v. China Minmetals Corp., 654 F.3d 462 (3d Cir. 2011).

60 See In re Marriage of Song \& Ye, No. Ho30253, 2007 WL 1475843, at * 5-7 (Cal. Ct. App. May 22, 2007) (interpreting Chinese marriage law).

61 See Lehman Bros. Commercial Corp. v. Minmetals Int'l Non-Ferrous Metals Trading Co., 179 F. Supp. 2d 118, 139-42 (S.D.N.Y. 2000) (determining that certain transactions violated multiple laws governing foreign exchange in China).

62 See Guangzhou Consortium Display Prod. Co. v. PNC Bank, Nat'l Ass'n, 924 F. Supp. 2d 800,812 n.7 (E.D. Ky. 2013) (citing Law on Wholly-Foreign Owned Enterprises).

63 See Huang v. Advanced Battery Techs., Inc., No. 09-8297, 2011 WL 813600, at *1-2 (S.D.N.Y. Mar. 8, 2011) (interpreting jurisdictional provisions of the Civil Procedure Law).

64 See Wurtz v. Bank of China Ltd., 979 F. Supp. 2d 479, 492-93 (S.D.N.Y. 2013) (ordering production of items "governed by Chinese privilege law").

65 See Hubei Gezhouba Sanlian Indus. Co. v. Robinson Helicopter Co., No. 06-1798, 2009 WL 2190187, at *5 (C.D. Cal. July 22, 2009) ("[T] he Civil Procedure Law of . . . China . . . controls the instant case.").

66 See Rapoport v. Asia Elec. Holding Co., 88 F. Supp. 2d 179, 184-85 (S.D.N.Y. 2000) (discussing whether a party's issuance of common stock violated Chinese law).

67 See Samsung Elec. Co. v. Early Bird Sav., No. 13-3105, 2014 WL 5139488, at *3-4 (S.D. Cal. Oct. 1, 2014) (deciding that party was not properly served under Chinese law); Chanel, Inc. v. Zhibing, No. 09-2835, 2010 WL 1009981, at ${ }^{*} 5$ n.3 (W.D. Tenn. Mar. 17, 2010) (concluding on basis of China's Civil Procedure Law that "[s]ervice by e-mail does not appear to violate Chinese law"); Dragas Mgmt. Corp. v. Taishan Gypsum Co., No. 11-8663, 2015 WL 10765166, at *2-4 (Va. Cir. Ct. June 16, 2015) (assessing refusal of service under Chinese law).

68 See Meggitt (Orange County), Inc. v. Nie Yongzhong, No. 13-0239, 2015 WL 1809354, at *7-8 (C.D. Cal. Apr. 21, 2015) (describing magistrate judge's rejection of a party's effort to seek protection under Chinese state secrecy laws).

69 See In re Air Crash Near Clarence Ctr., 983 F. Supp. 2d 249, 253 (W.D.N.Y. 2013) (determining the kind of compensatory damage typically awarded for wrongful death under Chinese law); Wultz v. Bank of China Ltd., No. 11-1266, 2012 WL 5431013, at *3-6 (S.D.N.Y. Nov. 5, 2012) (applying Chinese laws of negligence, breach of duty, and vicarious liability); Zim Integrated Shipping Servs., Ltd. v. Belco Res., Inc., No. 07-5861, 2008 WL 1959041, at *6-7 (S.D.N.Y. May 2, 2008) (assessing misrepresentation, fraud, failure to warn, and strict liability under Chinese law).

70 See Nautilus, Inc. v. ICON Health \& Fitness, Inc., 304 F. Supp. 3d 552, 559-61 (W.D. Tex. 2018); Lilith Games (Shanghai) Co. Ltd. v. UCool, Inc., No. 15-1267, 2015 WL 5591612, at *4 (N.D. Cal. Sept. 23, 2015) (interpreting copyright ownership under Chinese law); King.com Ltd. v. 6 Waves LLC, No. 13-3977, 2014 WL 1340574, at *2 (N.D. Cal. Mar. 31, 2014) (assessing scope of protection under Chinese copyright law); Splitfish AG v. Bannco Corp., 727 F. Supp. 2d 461, 465-66 (E.D. Va. 
American jurists have also had to evaluate Chinese law, either systemically or with respect to specific remedies. Generally, courts in the United States will not dismiss a suit to another forum for forum non conveniens if they deem the foreign forum inadequate, nor will they recognize a foreign judgment rendered in a judicial system lacking in impartial tribunals. ${ }^{71}$ The modern trend is to hold that Chinese laws and institutions mostly satisfy these baseline standards for due process. ${ }^{72}$ But courts have sometimes declared the adequacy prong unmet when Chinese law did not appear to afford an effective remedy or if the moving parties failed to sufficiently show adequacy. ${ }^{73}$

American judges have had to consult a panoply of Chinese legal sources. ${ }^{74}$ Such sources include, at the apex, national-level laws such as the Civil Procedure Law.75 At a level lower, they include implementing regulations issued by the State Council, China's chief administrative authority. 76 Courts have also looked to various forms of judicial guidance. These include the Supreme People's Court's (SPC) judicial interpretations-quasi-legislative guidance documents issued by China's highest court77-as well as more familiar forms of judicial guidance, from

2010) (finding that plaintiff owns copyright "as a matter of Chinese law"); cf. Fairchild Semiconductor Corp. v. Third Dimension (3D) Semiconductor, Inc., 589 F. Supp. 2d 84, 89-98 (D. Me. 2008) (determining whether to exercise jurisdiction despite "complexities of Chinese patent law").

71 For a more extensive discussion of these doctrines, see infra Section I.C.

72 See, e.g., Zheng v. Soufun Holdings, Ltd., No. 15-169o, 2016 WL 1626951, at * 4 (N.D. Ohio Apr. 25, 2016) (noting that "the United States Supreme Court and several federal courts have found, in similar cases, that the Chinese courts provide an adequate alternative forum" and listing cases); Folex Golf Indus., Inc. v. China Shipbuilding Indus., Corp., No. 09-2248, 2013 WL 1953628, at * 4 (C.D. Cal. May 9, 2013) (asserting that "U.S. courts consistently acknowledge the adequacy of due process in the PRC judicial system" and listing cases), rev'd on other grounds sub nom. Folex Golf Indus., Inc. v. O-Ta Precision Indus. Co., 603 F. App'x 576 (9th Cir. 2015); see also King.com, 2014 WL 1340574, at ${ }^{*} 3$ (similar); New Classic Home Furnishings, Inc. v. Haining Nice Link Home Furnishings Co., No. 12-0125, 2012 WL 13015017, at *2 (C.D. Cal. June 4, 2012) (similar).

73 See RF Micro Devices, Inc. v. Xiang, No. 12-0967, 2013 WL 5462295, at *4 (M.D.N.C. Sept. 30, 2013) (finding that the defendant provided "insufficient evidence . . . that China would provide an adequate forum"); Am. Induction Techs. v. KBK, Inc., No. 11-0350, 2012 WL 12888112, at *10 (C.D. Cal. Apr. 17, 2012) (noting that a party "may not be able to obtain an effective remedy in Chinese courts"); Applied Materials, Inc. v. Advanced Micro-Fabrication Equip., Inc., No. 07-5248, 2008 WL 11398913, at * 7 (N.D. Cal. Feb. 29, 2008) ("[T]he Court is concerned that China may not provide an adequate remedy for Plaintiff's intentional interference with a contract claim.").

74 Federal Rule of Civil Procedure Rule 44.1 permits federal judges to consider "any relevant material or source" when determining foreign law. FED. R. CIV. P. 44.1.

75 See, e.g., Chanel, Inc. v. Zhibing, No. 09-2835, 2010 WL 1009981, at *5 n.3 (W.D. Tenn. Mar. 17, 2010) (noting that service of process by email does not violate Chinese law).

76 See Lilith Games (Shanghai) Co. Ltd. v. UCool, Inc., No. 15-1267, 2015 WL 5591612, at * 4 (N.D. Cal. Sept. 23, 2015) (citing Regulations on Computer Software); Splitfish AG v. Bannco Corp., 727 F. Supp. 2d 461, 466 (E.D. Va. 2010) (cross-referencing the Chinese Copyright Law with the Computer Software Protection Regulations).

77 Nautilus, Inc. v. ICON Health \& Fitness, Inc., 304 F. Supp. 3d 552, 559-6o (W.D. Tex. 2018) (stating that "the appropriate sources of law are the statutory Patent Law, the Implementing Regulations of the Patent Law, and Supreme People's Court ("SPC") Interpretations of Law" (emphasis added)). 
ordinary judgments, which do not bind, to guiding cases, which are meant to have more authority. ${ }^{78}$ Several judges have even invoked the Chinese Constitution, ${ }^{79}$ which Donald Clarke once called "perhaps the least important document . . . in the entire Chinese system." 80 More on that to come.

For a taste of how American judges have had to wade into knotty questions of Chinese law, consider the case of Nautilus, Inc. v. ICON Health and Fitness, Inc., a patent suit filed in the Western District of Texas. ${ }^{81}$ Judge Royce Lamberth begins his analysis by reciting the diverse sources of Chinese law that govern his analysis: The Law on Choice of Law for Foreign Related Civil Relationships; the Patent Law; Several Provisions of the Supreme People's Court on Issues Relating to Application of Law to Adjudication of Cases of Patent Disputes; and the Interpretation of the Supreme People's Court on Several Issues Concerning the Application of Law in the Trial of Patent Infringement Dispute Case. ${ }^{82} \mathrm{He}$ then considers what weight to accord Chinese judicial decisions. He concludes that while guiding cases of the SPC have "precedential value," other decisions do not. ${ }^{83}$ Later in his decision, he cites to the Intellectual Property Bureau of Shantou, a city in Guangdong province. 84 "To be clear, the Shantou Intellectual Property Bureau's reasoning is in no way binding on this Court," he clarifies, "But it is persuasive." 85

Another important aid to determining foreign law is testimony from foreign law experts. Parties appearing in American courts have often retained established American scholars of Chinese law, including those based at Harvard, 86 NYU, 87 Georgetown, 88 George Washington University, 89 the

78 See Note, Chinese Common Law? Guiding Cases and Judicial Reform, 129 HARV. L. REV. 2213, 2224 (2016). Guiding cases are SPC-selected cases from any level of the judiciary that judges are expected to cite where relevant (though not as an independent source of law but rather as a "necessary aid to judicial reasoning"). See id. The system has been unevenly implemented. Id. at 2226-28.

79 See Trans Chem. Ltd. v. China Nat'l Mach. Imp. \& Exp. Corp., 978 F. Supp. 266, 280, 28384 (S.D. Tex. 1997); Wang Zong Xiao v. Reno, 837 F. Supp. 1506, 1542-43 (N.D. Cal. 1993).

80 Donald C. Clarke, Puzzling Observations in Chinese Law: When Is a Riddle Just a Mistake, in UNDERSTANDING CHINA'S LEGAL SYSTEM: EsSAYS IN HONOR OF JEROME A. COHEN 93, 103

(C. Stephen Hsu, ed., 2003).

81304 F. Supp. 3 d at $559-61$.

$82 \mathrm{Id}$. at $560-61$.

$83 \mathrm{Id}$. at $561-62$.

$84 \mathrm{Id}$. at 564 .

85 Id. (emphases added).

86 See Declaration of William P. Alford at 1, Tiffany (NJ) LLC v. Qi, 276 F.R.D. 143 (S.D.N.Y. 2011) (No. 10-9471), 2011 WL 13114893.

87 See Court Filed Expert Resume of Jerome A. Cohen at 26, Animal Sci. Prods., Inc. v. China Nat'l Metals \& Minerals Imp. \& Exp. Corp., 596 F. Supp. 2d 842 (D.N.J. 2008) (No. 054376), 2008 WL 8224019.

88 Declaration of Professor James V. Feinerman at 1, In re Vitamin C Antitrust Litig., 279 F.R.D. 90 (E.D.N.Y. 2009) (No. 06-1738), 2009 WL 5133516.

89 Declaration of Donald Clarke at 1, In re Chinese-Manufactured Drywall Prods. Liab. Litig., 2020 WL 836348 (E.D. La. Feb. 20, 2020) (No. 09-6530), 2016 WL 8539414. 
University of Pennsylvania, ${ }^{90}$ and UCLA. ${ }^{11}$ Parties have also enlisted prominent scholars based in Mainland or Greater China: Peking University, ${ }^{92}$ Tsinghua University, ${ }^{93}$ Renmin University, ${ }^{94}$ the University of Hong Kong, ${ }^{95}$ and the Chinese University of Hong Kong. ${ }^{96}$ Expert rosters have also included practitioners from major Chinese law firms, including King and Wood Mallesons, ${ }^{97}$ the Global Law Office, ${ }^{98}$ and Jun He. 99

Foreign law experts have played a substantial role in helping judges probe the fairness of China's legal system. In forum non conveniens cases, experts routinely duel over whether parties will receive a fair shake in Chinese court. For every report asserting that "Chinese law comprehensively protects" relevant rights and "would provide . . . a fair trial," there is another asserting that "[m]eaningful judicial independence does not exist in China." 100 Parties contesting adequacy have also cited public announcements of the Supreme People's Court, as well as declarations of lawyers who have sought and failed to file suit in China.101 In the foreign judgments recognition setting, parties have sometimes relied on State Department country reports and travel notices warning of judicial corruption, Party interference, and lawyer harassment.102

90 Declaration of Jacques deLisle at 1, In re Air Crash Near Clarence Ctr., No. 09-0961 (W.D.N.Y. Aug. 13, 2013), 2013 WL 8104169.

91 Declaration of Randall Peerenboom in Support of Yb's Motion to Dismiss for a Forum of Non Conveniens at 1, BP Chems. Ltd. v. Yankuang Grp. Boyang Foreign Econ. \& Trade Co., No. 038167 (C.D. Cal. Mar. 15, 2004), 2004 WL 3717191.

92 Declaration of Zhipan Wu at 1, Tiffany (NJ) LLC v. Qi, 276 F.R.D. 143 (S.D.N.Y. 2011) (No. 10-9471), 2011 WL 13115459

93 Declaration of Professor Xin Tang at 1, SEC v. Deloitte Touche Tohmatsu CPA Ltd., 940 F. Supp. 2 d 10 (D.D.C. 2013) (No. 11-0512), 2012 WL 12135758.

94 Affidavit of Prof. Dr. Liu Junhai at 1, In re Chinese-Manufactured Drywall Prods. Liab. Litig., No. 2047 (E.D. La. May 4, 2012), 2012 WL 3061667.

95 Donald Lewis Expert Rebuttal Report to Report of Ling Bing at 8, Southgate Master Fund, LLC v. United States, 651 F. Supp. 2d 596 (N.D. Tex. 2009) (No. 06-2335), 2008 WL 8200023.

96 Expert Report of Ling Bing at 2, Southgate Master Fund, 651 F. Supp. 2d 596 (No. 06-2335), 2008 WL 6626542.

97 Then known as King \& Wood. See Declaration of Mr. Liu Yuwu at 1, Apple \& Eve, LLC v. Yantai N. Andre Juice Co., 499 F. Supp. 2d 245 (E.D.N.Y. 2007) (No. 07-0745), 2007 WL 5444962.

98 Declaration of Meph Jia Gui in Support of Defendant 6waves LLC's Motion to Dismiss on Forumnon [sic] Conveniens Grounds at 1, King.com Ltd. v. 6 Waves LLC, 2014 WL 1340574 (N.D. Cal. Mar. 31, 2014) (No. 13-3977), 2013 WL 9586151.

99 Expert Witness Statement of Xiaolin Zhou, Genscript USA, Inc. v. Geneweiz, Inc., No. 6640-11 (N.J. Super. Ct. Law Div. Mar. 28, 2014), 2014 WL 7666393.

100 CYBERsitter, LLC v. People's Republic of China, No. 10-38, 2010 WL 4909958, at * 4 (C.D. Cal. Nov. 18, 2010) (alteration in original).

101 See, e.g., Tang v. Synutra Int'l, Inc., No. 09-0088, 2010 WL 1375373, at *6-8 (D. Md. Mar. 29, 2010).

102 See, e.g., Armadillo Distrib. Enters., Inc. v. Hai Yun Musical Instruments Mfr. Co., No. 121839, 2014 WL 2815943, at * 4-5 (M.D. Fla. June 23, 2014) ("[Plaintiff] references the [U.S. State Department] 2013 Country Report on Human Rights Practices . . . to support its contention that China lacks 'fair public tribunals' and 'due process in judicial proceedings.'”). 
Cases involving Chinese law concentrate in certain hubs of the judiciary. The vast majority are heard in federal court.103 Within the federal system, district courts play a primary role in adjudicating questions of foreign law. Based on the statistics compiled earlier, the five district courts with the most exposure to Chinese law are the Southern District of New York, the Central District of California, the Northern District of California, the Eastern District of New York, and the Northern District of Illinois. ${ }^{104}$ These courts exercise jurisdiction over the most populous commercial centers in the country, including New York City, San Francisco, Los Angeles, and Chicago. All to say, their more cosmopolitan dockets are not unexpected.

\section{Application of Foreign Law}

Judges encounter foreign law in a variety of settings. Commonly, foreign law will enter a case following a choice-of-law analysis. 105 When two or more countries have a meaningful connection to a dispute, but their laws differ as to a relevant issue, the court must decide which country's law to apply. The court's decision will be guided by any number of choice-of-law rules, which can vary by state and cause of action. Today, some states still follow the traditional lex loci ("law of the place") rules of the First Restatement, at least in some areas; most others apply the "significant relationship" test of the Second Restatement; and still others conduct a "government interest" analysis. ${ }^{106}$ The details of these rules are less important for our purposes than the fact that they exist, and that in an age of vibrant cross-border activity, conflicts principles will often bring authoritarian laws before an American court. 107

Many points of domestic law can also turn upon the meaning of foreign law. 108 To grant a divorce petition, judges must typically determine whether the marriage was valid. ${ }^{109}$ For those married abroad, the marriage laws of their home

103 Of the 3960 composite China-related search hits in Westlaw on July 23, 2019, 3326 were cases heard in federal court.

104 The composite case count as of July 23, 2019 is as follows: S.D.N.Y. (406); C.D. Cal. (186); N.D. Cal. (130); E.D.N.Y. (99); and N.D. Ill. (70).

105 See NiSHITANI, supra note 8, at 6.

106 See ClYDE SPILlENGER, PRINCIPLES OF CONFLICT OF LAWS 1-23, 95-102, 106-20 (2015); Peter Hay, The United States: The Use and Determination of Foreign Law in Civil Litigation in the United States, in NiSHITANI, supra note 8, at 401-02.

107 See, e.g., Godbey v. Frank E. Basil, Inc., 603 F. Supp. 775, 776-77 (D.D.C. 1985) (determining that Saudi law applies to plaintiff's contract and tort claims).

108 See, e.g., Hans W. Baade, The Operation of Foreign Public Law, 30 TEX. INT'L L.J. 429, 448 (1995) (previewing the role of "foreign public law as datum"). For a helpful list of other doctrines, see Zachary D. Clopton, Judging Foreign States, 94 WASH. U. L. REV. 1, 15-16 (2016).

109 See Eugene Volokh, Foreign Law in American Courts, 66 OKLA. L. REV. 219, 228 (2017). 
countries generally govern. ${ }^{110}$ Eugene Volokh describes a divorce case, ${ }^{111}$ not at all atypical, in which a Louisiana court looked to Iranian law to determine whether a couple was validly married.112 Foreign authoritarian law issues can also arise in cross-border litigation. A party might seek to suppress a foreign deposition on the ground that it did not comply with local law, ${ }^{113}$ or move to limit discovery of evidence abroad for fear of violating foreign state secrecy laws. ${ }^{114}$ The same story unfolds in immigration law. Circuit courts have vacated orders where the immigration judge "may have erred" in their understanding of foreign law. ${ }^{115}$ In asylum cases, judges have scrutinized the text of foreign laws to determine whether they contemplate conduct "performed by force." 116 Petitioners have lost cases after failing to submit proper "proof" of law.117

The modern practice, operative in most state courts and in federal court, is to treat foreign law not as a fact to be pleaded and proven, but as law, to be determined by a judge. 118 Federal Rule of Procedure 44.1, which has been adopted by a number of states, 119 provides that:

A party who intends to raise an issue about a foreign country's law must give notice by a pleading or other writing. In determining foreign law, the court may consider any relevant material or source, including testimony, whether or not submitted by a party or admissible under the Federal Rules of Evidence. The court's determination must be treated as a ruling on a question of law.120

Rule 44.1 empowers federal judges to consult independently a range of sources when considering foreign law. ${ }^{121}$ But given caseloads, expertise

110 See id.

111 Ghassemi v. Ghassemi, 998 So. 2d 731 (La. Ct. App. 2008).

112 Id.; see also Volokh, supra note 109, at 228.

113 See Popular Imports, Inc. v. Wong's Int'l, Inc., 166 F.R.D. 276, 277-78 (E.D.N.Y. 1996) (seeking suppression of voluntary depositions taken on Chinese soil because "the unsworn depositions were illegal" under Chinese law).

114 See Autodesk, Inc. v. ZWCAD Software Co., No. 14-1409, 2015 WL 1928184, at *3-9 (N.D. Cal. Mar. 27, 2015) (denying protective order where moving party failed to prove that subject matter was covered by Chinese state-secrets law).

115 Lian v. Gonzales, 201 F. App'x 808, 810 (2d Cir. 2006).

116 Xian Ming Jiang v. Holder, 430 F. App'x 39, 41-42 (2d Cir. 2011).

117 Xiao Hong Fu v. Gonzales, 241 F. App'x 713, 714 (2d Cir. 2007).

118 See Hay, supra note 106, at 405. For a thorough account of the transition away from a "fact" approach to determinations of foreign law, see Miller, supra note 8 .

119 See, e.g., MASs. R. CIV. P. 44.1.

120 FED. R. CIV. P. 44.1.

121 See FED. R. CIV. P. 44.1 advisory committee's note ("The court may have at its disposal better foreign law materials than counsel have presented, or may wish to reexamine and amplify material that has been presented by counsel in partisan fashion or in insufficient detail."). 
deficits, and the adversarial setting in general, judges typically rely on sources cited in expositions of foreign law provided by the parties or their experts. ${ }^{122}$

Finally, courts must sometimes evaluate foreign law or institutions as well. Judges may have to assess foreign laws while managing discovery ${ }^{123}$ or while considering forum selection clauses, stays, and antisuit injunctions. ${ }^{124}$ Perhaps the most common "evaluative" doctrines in the authoritarian law setting are those concerning forum non conveniens and foreign judgments recognition. A party can defeat a forum non conveniens motion by arguing that the alternative forum is inadequate, either because the remedies available in the alternative forum are unsatisfactory, 125 or because that forum's legal system as a whole is too broken or corrupt. ${ }^{126}$ Similarly, parties can persuade a court to refuse recognition and enforcement of a foreign judgment either by pointing to deficiencies in the foreign proceeding, ${ }^{127}$ or by showing generally that the foreign judicial system "does not provide impartial tribunals or procedures compatible with the requirements of due process of law."128 Courts are likelier to reject forum non conveniens arguments or to make "inadequacy" determinations when the alternative forum is not a liberal democracy. ${ }^{129}$

\section{The Distinct CHALLENGE OF ILLIBERAL LAW}

To show why authoritarian law presents a special problem, I begin by outlining the sorts of challenges associated with foreign law in general. Such problems, though challenging in their own right, tend to stress only legal differences that vary within a specific notion of modernist legality. That is, we tend to assume that-whatever the differences between System A and System

122 See Pollack, supra note 8, at 471 (1978) ("We have quite a few things to do besides decoding the Codigo Civil.").

123 See Clopton, supra note 108, at 17 (noting that courts will sometimes factor their substantive evaluations of foreign laws limiting discoverability into how they manage discovery noncompliance).

124 See id. at 19; see also TSMC N. Am. v. Semiconductor Mfg. Int'l Corp., 74 Cal. Rptr. 3d 328, 331 (Ct. App. 2008) (affirming denial of motion for antisuit injunction pertaining to court in Beijing).

125 See Piper Aircraft Co. v. Reyno, 454 U.S. 235, 254 n.22 (1981).

126 See, e.g., Guimei v. Gen. Elec. Co., 91 Cal. Rptr. 3d 178, 187-88 (Ct. App. 2009) (describing how plaintiffs painted a stark picture of the Chinese legal system).

127 See, e.g., Chevron Corp. v. Donzinger, 974 F. Supp. 2d 362, 604-17 (S.D.N.Y. 2013) (refusing to recognize Ecuadorian judgment due to perceptions of corruption and fraud).

128 UNIFORM FOREIGN-COUNTRY MONEY JUDGMENTS RECOGNITION ACT (UFCMJRA) $\S 4(b)(1), 13$ pt. 2 U.L.A. 26 (UNIF. LAW COMM'N 2005). A majority of states have enacted a version of the UFCMJRA. See Christopher A. Whytock \& Cassandra Burke Robertson, Forum Non Conveniens and the Enforcement of Foreign Judgments, 111 COLUM. L. REV. 1444, 1464-65 (2011).

129 See Michael T. Lii, An Empirical Examination of the Adequate Alternative Forum in the Doctrine of Forum Non Conveniens, 8 RICH. J. GLOBAL L. \& BUS. 513, 537-39 (2009) (comparing findings of adequacy); Christopher A. Whytock, The Evolving Forum Shopping System, 96 CORNELL L. REV. 481,525 (2011) (comparing overall dismissal rates). 
B - both involve something called "law," which, defined minimally enough, all systems share.

Authoritarian legal systems, I will show, have a systematic tendency to defy modernist concepts of legality. Documents that resemble laws in form may carry little such authority in practice. In other areas, prescripts lacking in the trappings of legality may nevertheless bind with the force of law. As for courts, the institutional cornerstones of modernist law, a stated commitment to neutral decisionmaking may be nothing more than pretense. These deviations from modernism can unsettle basic assumptions about legality, raising a number of novel and underappreciated questions of legal interpretation.

Two additional problems bear mention. First, authoritarian legal systems today can be bifurcated, in that some areas of law may evince deviations from modernism while other areas may otherwise conform. Second, judges called to interpret the laws of a foreign authoritarian system might themselves be biased in ways that inhibit accurate interpretation. Both problems-bifurcation and bias-are in their own ways distinct to autocratic law, and so present their own set of interpretive difficulties.

\section{A. The Modernist Paradigm of Foreign Law}

When a judge interprets another country's laws, she must have in mind a set of basic assumptions about what law is and how law works. Defined minimally enough, these assumptions are shared between judges across the spectrum of modern legal systems. In this common paradigm, "law" consists of written rules enacted by the state pursuant to recognized procedures; these rules more or less conform with Lon Fuller's principles of legality for guiding conduct, that is, they are general, public, prospective, consistent, understandable, stable, and roughly congruent with their implementation ${ }^{130}$; and such rules are enforced within a triadic model of institutionalized dispute resolution, based upon a neutral application of specialized reasoning.131 The

130 See LON FUlLER, THE MORALiTy OF LAW 39, 46-91 (1964). Fuller believed that for law to serve its essential function of guiding behavior, it must minimally conform to eight principles: the rules must be expressed in general terms; the rules must be publicly promulgated; the rules must be prospective; the rules must be expressed in understandable terms; the rules must be consistent with each other; the rules cannot require conduct outside of the capabilities of those affected; the rules cannot be altered so often as to frustrate reliance; and the rules as implemented must be congruent with the rules as written. See id. Other theorists have described similar principles as constituting basic conditions for "the rule of law." See, e.g., Richard H. Fallon, "The Rule of Law" as a Concept in Constitutional Discourse, 97 COLUM. L. REV. 1, 8-9, 8 n.27 (1997) (emphasizing five elements of the Rule of Law that are "in spirit consistent with . . . Lon Fuller's account of eight criteria"); Joseph Raz, The Rule of Law and its Virtue, in THE AUTHORITY OF LAW: EsSAYS ON LAW AND MORALITY 214, 214-15 (Joseph Raz ed., 1979) (arguing that "all laws should be prospective, open, and clear" and that "laws should be relatively stable").

131 Martin Shapiro describes a triadic model of conflict resolution as "[s]o universal across both time and space ... that we can discover almost no society that fails to employ it." MARTIN 
paradigm is crosscutting in that many illiberal systems that deviate from this paradigm may still speak of it as normatively appealing or characteristic of their law. ${ }^{132}$ For that reason, I will sometimes refer to this as the "universalist" or "modernist" conception of law.

For a sense of how the paradigm underlies common thinking on foreign law interpretation, consider the late Judge Milton Pollack's exhortation that federal judges need not fear foreign law:

Of course, arguing foreign law is more complex than when the law is domestic . . . . Yet, if what is relied upon is law, and not some primitive religion or the whim of a tyrant, the form of reasoning will be familiar. In civil law countries, the express language of statutes may be entitled to more weight than we give it, and judicial decisions to less-but the law is still proved by pronouncements of suitably constituted authorities. I am told that in Mexico a single decision construing a statute has no precedential effect, but that a line of consistent decisions has. That's not our rule, but the notions of precedent and construction are familiar, and an American court can understand and apply the Mexican rule if it is called to the court's attention.133

Judge Pollack begins by assuming there is something called "law," common across countries, that can be accessed through a "form of reasoning" shared across legal systems. He does not define "law," but he understands it to consist of "statutes" and other "pronouncements of suitably constituted authorities," especially "judicial decisions." Judge Pollack also tells us what law is not: a "primitive religion or the whim of a tyrant." Law must therefore have properties that ancient superstitions and dictatorial whims lack-stability probably, and consistency, generality, congruence-qualities that would seem to approximate some version of Fuller-ian legality.

The modernist paradigm sketches only a thin outline of a system. The details that fill this outline can vary greatly-lawmakers can be centralized legislators or a diffuse community judges; laws can be organized as codes or statutes or in case reporters; judges can be passive or inquisitorial; religion

SHAPIRO, COURTS: A COMPARATIVE AND POLITICAL ANALYSIS 1 (1981). Jeremy Waldron argues that all legal systems must include courts, defined as "institutions that apply norms and directives established in the name of the whole society to individual cases, that settle disputes about the application of those norms, and that do so through the medium of hearings." Jeremy Waldron, The Concept and the Rule of Law, 43 GA. L. REV. 1, 20 (2008). Many theorists consider neutral courts to be essential to the "rule of law." See, e.g., Fallon, supra note 130, at 9 (highlighting the need for courts as "instrumentalities of impartial justice"); Raz, supra note 130, at 216-17 (listing judicial independence as a criterion).

132 Of course liberal systems may also fall short of the paradigm, which functions here as an ideal-type concept.

133 See Pollack, supra note 8, at 474. 
can play various roles in the state administration of law; and informal means of dispute resolution may coexist alongside formal law.

When judges articulate difficulties raised by foreign law, they tend to highlight differences that fall within the ambit of these variations. Consider the question of how common-law judges ought to relate to civil law systems-a longstanding problem in the field. ${ }^{134}$ Can American judges accurately apply continental law? 135 How much weight should be accorded to statutes, judicial decisions, or treatises?136 Are the two systems close enough as to preclude the need for experts?137 Though unquestionably important, these questions do not unsettle the modernist equilibrium. One can parse distinctions between civil and common law without departing from the thin outline of legality shared in theory between both systems. ${ }^{138}$

Consider next the problem of legal-cultural translation: How do judges capture the nuance of laws promulgated in a different legal setting, often in a different language? On one end is Justice Holmes' despair-laden description of the Puerto Rican legal system as appearing to him a "wall of stone, every part even with all the others," except where his "own local education" revealed the "subordinations to which [he was] accustomed." 139 On the other end is Judge Richard Posner's conviction that judges rarely require expert testimony

134 See E. Gerli \& Co. v. Cunard S.S. Co., 48 F.2d 115, 117 (2d Cir. 1931) ("The extent of our right to make any assumptions about the law of another country depends upon the country and the question involved; in common-law countries we may go further than in civil law . . . ."); ОTTO C. SOMMERICH \& BENJAMIN BUSCH, FOREIGN LAW: A GUIDE TO PLEADING AND PROOF 120-21 (1959) ("Honesty requires admission on the part of bench and bar alike of relative unfamiliarity with the laws of civil code countries . . . ."); Wilson, supra note 8, at 890-91 (predicting that "adjudicators trained in common law jurisprudence are likely to be less comfortable looking at the application of law formulated in a civil system").

135 Compare Diaz v. Gonzalez, 261 U.S. 102, 106 (1923) (Holmes, J.) (describing how the "varying emphasis, tacit assumptions, unwritten practices" in a civil law system renders it exceedingly difficult to understand for an outsider), with Pollack, supra note 8, at 474 (stating that he is "less pessimistic than Justice Holmes").

136 See, e.g., Ancile Inv. Co. v. Archer Daniels Midland Co., 538 F. App’x 19, 21 \& n.2 (2d Cir. 2013) (addressing party's argument based on the "limited role of precedent in the Brazilian legal system," which follows "civil law"). This issue can also arise domestically when federal courts interpret Louisiana or Puerto Rican law. See, e.g., In re Orso, 283 F.3d 686, 695 (5th Cir. 2002) (describing how Louisiana state "court decisions . . . [lack] stare decisis precedential effect"); In re San Juan Dupont Plaza Hotel Fire Litig., 687 F. Supp. 716, 726 (D.P.R. 1988) (explaining how in the Puerto Rican civil law system, the work of tratadistas, or treatise-writers, "may even be more influential than a court decision").

137 See Bodum USA Inc. v. La Cafetière, Inc., 621 F.3d 624, 633-38 (7th Cir. 2010) (Posner, J., concurring) (arguing that judges need not rely on experts to interpret foreign law).

138 Cf. In re Angeles Roca First Judicial Dist. Phila. Cty., 173 A.3d 1176, 1201-202 (Pa. Sup. Ct. 2017) (Donohue, J., dissenting) ("Most nomocratic nations, i.e., nations that adhere to the rule of law, follow one of two major legal traditions that act to cabin the discretion of judges: the civil law system or the common law system.").

139 Diaz, 261 U.S. at 106. 
to accurately determine foreign law. ${ }^{140}$ Despite their differences, both judges subscribe to modernism. Justice Holmes, in the above quotation, did not suggest that Puerto Rican law defied foundational principles of legality, only that variations in "emphasis in the reading of" the Puerto Rican civil code could lead to different interpretations. ${ }^{141}$ Meanwhile, Judge Posner's modernist assumptions shine through in his faith that judges are wellequipped to interpret most all foreign laws. After all, he says, "judges are experts on law." 142

Some caveats. I do not claim that all judges believe that law everywhere satisfies basic conditions of modernism. Nor do I claim that law anywhere satisfies a pure version of the modernist ideal. But given that one cannot interpret foreign law without some preexisting conception of what law is, it behooves us to understand what that concept might be. My claim is that American judges commonly default to a framework that resembles the thin sketch of legality outlined in the modernist paradigm (if not something more substantively demanding ${ }^{143}$ ). As a result, accounts of the challenges of foreign law tend to focus on systemic variations within a modernist framework. Understudied and misunderstood are the interpretive challenges posed by legal systems that depart from modernist legality.

\section{B. Authoritarian Legality}

In illiberal nations, departures from modernism are often driven by a coherent authoritarian logic. When it comes to law, autocrats face a basic existential dilemma-how to extract the benefits of modernist legality without empowering courts and activists to challenge the core interests of the regime. Though solutions to this dilemma vary among countries, the resulting departures from modernism tend to be similar-written "laws" that do not bind, hidden norms that do, and "courts" that bend to political interests.

\section{The Logic of Authoritarian Legality}

For the rational autocrat, law can serve a number of important goals. ${ }^{144}$ Perhaps the most conventional such goal is social control. Courts assist the regime in "maintain[ing] order and . . . sidelin[ing] political opponents," either alone or in concert with other supervisory instruments-parties, police,

140 See Bodum, 621 F.3d at 633 (Posner, J., concurring).

141 Diaz, 261 U.S. at 106.

142 Bodum, 621 F.3d at 633 (Posner, J., concurring).

143 See infra Section II.C (discussing liberal biases).

144 For an overview of the literature on authoritarian legality, see generally Tamir Moustafa, Law and Courts in Authoritarian Regimes, 10 ANN. REV. L. SOC. SCI. 281 (2014). 
and military. ${ }^{145}$ Relatedly, law can also figure into social management, guiding conduct and directing disgruntled citizens away from protest and into courtrooms. ${ }^{146}$ With stability comes predictability, helping to signal credible commitments to investors. ${ }^{147}$ Modern autocracies are well attuned to the link between secure property and contract rights and economic growth, especially in a world of mobile capital. ${ }^{148}$ Better enforced laws can also help police wayward bureaucrats and other actors, ${ }^{149}$ empowering citizens to check local

145 See Tamir Moustafa \& Tom Ginsburg, Introduction to RULE BY LAW: THE POLITICS OF COURTS IN AUTHORITARIAN REgIMES 1, 4-5 (Tom Ginsburg \& Tamir Moustafa eds., 2008) [hereinafter RULE BY LAW] (discussing examples from the Soviet Union, Brazil, Chile, Argentina, Turkey, and Iran). Stalinist show trials, for instance, "utilized courts for political education . . . , employing the form of law without any autonomy given to courts." Id. at 4.

146 See Benjamin L. Liebman, A Return to Populist Legality? Historical Legacies and Legal Reform, in MAO'S INVISIBLE HAND: THE POLITICAL FOUNDATIONS OF ADAPTIVE GOVERNANCE IN CHINA 165, 168 (Sebastian Heilmann \& Elizabeth J. Perry eds., 2011) (asserting that Chinese "law is also being used to create new norms" in such areas as employment law and intellectual property); Benjamin L. Liebman, Legal Reform: China’s Law-Stability Paradox, DÆDALUS, Spring 2014, at 96, 96.

147 See Moustafa \& Ginsburg, supra note 145, at 8-9 ("Courts provide transparent, nominally neutral forums to challenge government action, and hence are useful for foreign investors and trade.").

148 Judge Richard Posner, among others, has argued that "[a] modernizing nation's economic prosperity requires at least a modest legal infrastructure centered on the protection of property and contract rights." Richard A. Posner, Creating a Legal Framework for Economic Development, 13 WORLD BANK RES. OBSERVER 1, 1 (1998). A number of scholars have linked greater investments in legality to returns in economic growth. See, e.g., Jothie RajaH, Authoritarian Rule Of LAW: LEGISLATION, DisCOURSE, AND LEGITIMACY IN SINGAPORE 1-3 (2012) (arguing that Singapore relies on strong rule-of-law scores to attract and keep global capital); YUHUA WANG, TYING THE AUTOCRAT'S HANDS: THE RISE OF THE RULE OF LAW IN CHINA 48-49 (2015) (contending that China has adopted a "partial" rule of law to woo politically unconnected interest groups who control valuable mobile assets); Jacques deLisle, Law and the China Development Model, in IN SEARCH OF ChinA's DeVelopment Model: Beyond the Beijing Consensus 147, 148 (S. Philip Hsu et al. eds., 2011) (arguing that "law has occupied . . . a striking, unprecedented place" in China's "design for economic progress with political stability"); James V. Feinerman, New Hope for Corporate Governance in China?, 2007 CHINA Q. 590, 590 (pointing to better corporate governance as a "vital link in bringing capital to China"); Tamir Moustafa, Law and Resistance in Authoritarian States: The Judicialization of Politics in Egypt, in RULE BY LAW, supra note 145, at 132, 133-39 (describing how economic development was a primary reason for Egyptian judicial reforms in the late 1970s). But see Donald C. Clarke, Peter Murrell \& Susan H. Whiting, The Role of Law in China's Economic Development, in CHINA's GREAT ECONOMIC TRANSFORMATION 375, 375-76 (Thomas Rawski \& Loren Brandt eds., 2008); Shitong Qiao \& Frank K. Upham, China's Changing Property Law Landscape, in COMPARATIVE PROPERTY LAW: GlOBAL PERSPECTIVES 311, 311 (Michele Graziadei \& Lionel Smith eds., 2017). Autocratic governments can also instrumentalize criminal laws in the service of economic goals. See Margaret K. Lewis, Criminal Law Pays: Penal Law's Contribution to China's Economic Development, 47 VAND. J. TRANSNAT'L L. 371, 417 (2014) (“[R]ecent events indicate that the PRC government not only is continuing to use criminal law in service of economic ends but also doing so in new and varied ways.").

149 See Moustafa \& Ginsburg, supra note 145 , at 7-8 (explaining that authoritarian regimes have difficulty collecting information "because the typical mechanisms for discovery, such as free press or interest groups that monitor government behavior, are suppressed to varying degrees”). 
malfeasance that defies or embarrasses the political center. ${ }^{150}$ Finally, legality can promote domestic and international legitimacy: it can give the impression that autocratic rule is constrained, ${ }^{151}$ foster positive perceptions of leaders, ${ }^{152}$ and confer a "formal legitimacy . . . [within] the club of modernity."153

At the heart of these functions is the idea of instrumental legality (sometimes called "rule by law"), the notion that autocrats seek to rule through law without themselves being constrained by it. ${ }^{154}$ The problem, of course-indeed the basis of the autocrat's dilemma-is that the greater the investment in legality, the greater the risk that law will be used to undercut the regime's hold on power. Law then can be what William Alford terms a "dual-edged sword."155 Freed from constant political supervision, courts may rule in ways opposite to regime interests. ${ }^{156}$ Buoyed by the rhetoric of "rule of law," lawyers and activists may use the language of law to lobby against state policies, or even the regime itself. 157 The authoritarian solution to this

150 See id. (describing how various regimes have used courts to enhance bureaucratic compliance); see also MARY E. GALLAGHER, AUTHORITARIAN LEGALITY IN CHINA: LAW, WORKERS, AND THE STATE 5 (2017) (explaining how the Chinese government relied on workers to enforce its new labor regulation regime); Moustafa, supra note 148, at 139-46; Taisu Zhang \& Tom Ginsburg, China's Turn Toward Law, 59 VA. J. INT'L L. 306, 312 (2019). But see Wei Cui, Does Judicial Independence Matter? A Study of the Determinants of Administrative Litigation in an Authoritarian Regime, 38 U. PA. J. INT'L L. 941, 993-96 (2017) (explaining that "administrative litigation may be deprived of its significance" because "laws that courts would enforce may be unfavorable to would-be plaintiffs" and "that private parties may themselves benefit from . . . a social order that is inconsistent with the rule of law").

151 See Moustafa \& Ginsburg, supra note 145, at 5-6 (listing examples); Margaret K. Lewis, Controlling Abuse to Maintain Control: The Exclusionary Rule in China, 43 NYU J. INT'L. L. \& POL. 630, 685-87 (2011) ("The motivation at the highest level to at least be seen as responding to public concerns regarding governmental abuse is apparent.").

152 See Moustafa \& Ginsburg, supra note 145, at 33. Legitimacy returns can exist even if new laws are merely symbolic. See Alex L. Wang, Symbolic Legitimacy and Chinese Environmental Reform, 48 ENVTL. L. 699, 700 (2018) (discussing "the ways in which symbolic reform works in China's authoritarian setting").

153 Moustafa \& Ginsburg, supra note 145 , at 6 . Brian Tamanaha calls the rule of law "the preeminent legitimating political ideal in the world today." BRIAN Z. TAMANAHA, ON THE RULE OF LAW: HISTORY, POLITICS, THEORY 4 (2004); see also Law \& Versteeg, supra note 23, at 170.

154 See Randall PeErenboom, China's Long March Toward Rule of LaW 8, 23 (2002) ("[R]ule by law refers to an instrumental conception of law in which law is merely a tool to be used as the state sees fit."); TAMANAHA, supra note 153, at 91-93 (noting that "[r]ule by law carries scant connotation of legal limitations on government").

155 William P. Alford, Double-Edged Swords Cut Both Ways: Law and Legitimacy in the People's Republic of China, DÆDALUS, Spring 1993, at 45, 62 (reflecting on how law can become a "legal, moral, and political vocabulary" and courts "a singular platform from which . . . concerns might be broadcast").

156 See Moustafa \& Ginsburg, supra note 145, at 12-13.

157 See, e.g., Sida liu \& Terence C. Halliday, Criminal Defense in China: The POLITICS OF LAWYERS AT WORK 2-7 (2016) (arguing that "a fraction of China's lawyers . . . strive in practice for the restraint of state power"); Lynette J. Chua, Pragmatic Resistance, Law, and Social Movements in Authoritarian States: The Case of Gay Collective Action in Singapore, 46 LAW \& SOC'Y REV. 713,714 (2012) (examining how the gay rights movement in Singapore made gains by "accept[ing] 
dilemma is not usually to retreat from law entirely, but instead to cultivate a distinctive set of institutions and practices seeking to isolate the benefits of legality while minimizing its risks. The result is a legal system that resembles modernist legality in some ways, but departs from it in others.

\section{Departures from "Modernism"}

Authoritarian law can systematically diverge from modernist legality in several ways. These divergences trace to the state's wariness of legal constraints, 158 as well as fragmentations that are often associated with authoritarian rule. For modernist judges who encounter such laws, the interpretive problems can be both novel and vexing.

\section{a. "Sham" Laws}

An initial point of departure: authoritarian legal systems often contain documents that present to the world as "laws" but are in practice not enforced. The most prominent of these "laws" are constitutions. North Korea's Constitution promises "freedom of speech, of the press, of assembly, demonstration, and association." 159 In reality, "North Korea is a one-party state led by a dynastic totalitarian dictatorship." 160 Constitutions whose "provisions are not upheld in practice" are sometimes called sham constitutions. ${ }^{161}$ Unsurprisingly, authoritarian countries are especially likely to have them. ${ }^{162}$

Autocrats have straightforward reasons for fearing constitutional enforcement. Constitutions tend to address questions of public power and human rights. Naturally, efforts to meaningfully enforce constitutions will

law's discipline and control"); Mark Jia, China's Constitutional Entrepreneurs, 64 AM. J. COMP. L. 619, 633-59 (2016) (analyzing how activists leveraged state "rule of law" discourses to advocate against the constitutionality of state policies); Liebman, supra note 146, at 171 ("The party-state's rhetorical commitment to legality and emphasis on popular legal education have legitimized rights-based actions by individuals."); Bui Ngoc Son, Constitutional Mobilization, 17 WASH. U. GLOBAL STUD. L. REV. 113, 156-58 (2018) (discussing how LGBT activists sought to establish a constitutional basis for same-sex marriage in Vietnam); Rachel E. Stern \& Kevin J. O'Brien, Politics at the Boundary: Mixed Signals and the Chinese State, 38 MOD. CHINA 174, 183 (2012) (discussing "boundary-pushing lawyers").

158 William Alford observed that Chinese leaders' "unwillingness . . . to cede major authority to the law in a meaningful and consistent fashion has undercut the very stability, predictability, neutrality, and autonomy that comprise the essence of legality, distinguish it from politics, and, ultimately, constitute its particular virtue." WILLIAM P. ALFORD, TO STEAL A BOOK IS AN ELEGANT OFFENSE: INTELLECTUAL PROPERTY LAW IN CHINESE CIVILIZATION 94 (1995).

159 Socialist Constitution of the Democratic PeOple's Republic of Korea, Sept. 5,1998 , art. 67 .

160 FrEEDOM HOUSE, FREEDOM IN THE WORLD 2018: NORTH KOREA (2018), https://freedomhouse.org/country/north-korea/freedom-world/2018 [https://perma.cc/RRP8-ZUCQ].

161 See David S. Law \& Mila Versteeg, Sham Constitutions, 101 CALIF. L. REV. 863, 880 (2013).

162 See Law \& Versteeg, supra note 23, at 175-178 (presenting data showing that "authoritarian regimes are, on the whole, more prone to sham constitutionalism than democratic regimes"). 
risk constraining state power, fettering the ultimate deciders. ${ }^{163}$ Sham constitutions, though, can well serve authoritarian interests. They can appease constituencies or political opponents; they can signal policy changes, priorities, or aspirations to a domestic or international audience; they can "cheap[ly]" indicate facial conformity with global standards; and-even if the rights-conferring provisions aren't observed-they can still describe government operations so as to coordinate state activity. ${ }^{164}$ By drawing up a "Constitution," calling it "law," but then crippling its enforcement, authoritarians can extract some of the benefits of constitutions without suffering the worst of their costs.

Ordinary authoritarian laws can reflect a similar calculus. Autocrats may adopt laws to facially conform with international agreements or expectations, with no intent to implement them. 165 Governments may issue rules or policies that vary or flout laws that have not been rescinded or formally modified. 166 Other laws may be worded generally but in reality exempt certain parties from enforcement. For example, criminal laws that purport to govern universally may not apply or apply differently to large swaths of the political elite. ${ }^{167}$ Or in matters of trade and investment, leaders may treat laws "more as starting points for negotiation than as mandatory norms." 168

Sham laws can pose a serious challenge for American judges. Though cloaked in the language of law-indeed in some cases constitutional law, the apex of law's dominion ${ }^{169}$ - the documents described above do not conform to modernist principles of legality. Congruence requires that there be at least

163 Modern constitutionalism traces back to the imposition of "fundamental law" upon English governance following the Glorious Revolution. See 1 ALFRED H. KELLY, WINFRED A. HARBISON

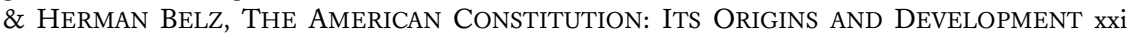
(1991). Harold Berman observed that "it is a basic postulate of the Soviet system . . . that law is essentially a means whereby the political leadership exercises control over society." Harold J. Berman, The Comparison of Soviet and American Law, 34 IND. L.J. 559, 567 (1959).

164 Tom Ginsburg \& Alberto Simpser, Introduction to CONSTITUTIONS IN AUTHORITARIAN REgimes 2, 5-10 (Tom Ginsburg \& Alberto Simpser eds., 2014); see also Law \& Versteeg, supra note 23, at 170-74.

165 Eritrea, for example, has a promulgated a detailed Electoral Law to secure a "free popular vote." See ERITREAN ELECTORAL LAW preamble, arts. 5, 11-12, 23-24, 41, 43. Eritrea, however, is a "militarized authoritarian state that has not held a national election since . . 1993." FREEDOM HOUSE, FREEDOM IN THE WORLD 2018: ERITREA (2018), https://freedomhouse.org/ country/eritrea/freedom-world/2018 [https://perma.cc/5UMK-W2TJ]. While local elections have happened, they are "controlled by the ruling party." Id.

166 See, e.g., Sijie Chen, China's Compliance with WTO Transparency Requirement: InstitutionRelated Impediments, AMSTERDAM L.F., Spring 2012, at 25, 44-45.

167 Chinese Communist Party members have historically been disciplined through internal party rules outside of the formal judicial system. See LUBMAN, supra note 52, at 170.

168 Donald C. Clarke, Legislating for a Market Economy, 2007 CHINA Q. 567, 569-70 (characterizing China's 1979 Law on Sino-Foreign Equity Joint Ventures).

169 For example, the Chinese term for "Constitution" contains the term "law" or $f a$. Its preamble describes the Constitution as possessing "supreme legal authority." XIANFA preamble (2004). 
a reasonable amount of similarity between the laws as written and the laws as practiced. ${ }^{170}$

Should American judges nevertheless respect superficial features of formality and apply all laws that present to the world as laws? Or should they preliminarily seek to ascertain which laws are sham? How might they do so? What if the issue is not official nonenforcement, but underenforcement to the point of dead letter? What if the issue is nonenforcement as to only certain parties? Do the reasons for nonenforcement matter? Questions such as these merit careful consideration.

\section{b. Hidden "Laws"}

While some authoritarian "laws" do not bind, other norms or commands that lack the hallmarks of legality can nonetheless regulate conduct with the force of law. For brevity, I refer to these as "hidden laws." Many autocracies, for example, have a practice of issuing laws and directives that are never publicized. 171 Consider one Chinese expert's characterization of Chinese regulatory law:

Many official requirements are ... transmitted through communications that may consist of department documents or oral directions, even including telephone calls. It is not the form of communication that creates its binding character, but the source and authority of the party giving the direction. Regardless of form, to the extent that these directions come from people in superior authority they are no less binding and obligatory on subordinates and the companies than any other type of "law."172

170 See FULLER, supra note 130, at 81-90.

171 See COMm. ON INT'L COMMERCIAL DisPuTE RESOlUTION ASS'N OF THE BAR OF THE City of N.Y., PROOF OF FOREIGN LAW AFTER FOUR DECADES WITH RULE 44.1 FRCP AND CPLR 4511, at 1 (2005), https://www.nycbar.org/pdf/report/International_Commercial_Dispute.pdf [https://perma.cc/G ${ }_{59} \mathrm{X}-7 \mathrm{YW}_{3}$ ] (noting that the law of some foreign countries "cannot readily be traced into objectively verifiable documents such as statutes and reports of judicial decisions"); Berman, supra note 163 , at 563 (stating that "some Soviet laws are unpublished"); Chen, supra note 166, at 27 ("China's administrative system was not designed for transparency."); Lon L. Fuller, Positivism and Fidelity to Law: A Reply to Professor Hart, 71 HARV. L. REV. 630, 651-52 (1958) (describing "secret laws" in Nazi Germany). American courts have taken note of this too. See, e.g., United States v. Pink, 315 U.S. 203, 220 (1942) (discussing unwritten Soviet law); Lau v. Kiley, 410 F. Supp. 221, 223 (S.D.N.Y. 1976) (noting that Maoist-era Chinese "[d]ecisions are not published in any reporting system, and few outsiders have been permitted to observe any legal proceeding"). For a discussion on the philosophical problem of "secret laws," see generally Claire Grant, Secret Laws, 25 RATIO JURIS 301 (2012).

172 Report of Shen Sibao (Feb. 19, 2009), in Joint Appendix on Writ of Certiorari to the United States Court of Appeals for the Second Circuit at 141, Animal Sci. Prods., Inc. v. Hebei Welcome Pharm. Co., 138 S. Ct. 1865 (2018) (No. 16-1220). 
In other regulatory contexts, hidden laws can sometimes take the form of "drawer" regulations-ministry-issued rules that, "even though not labeled secret, have not been publicly disseminated." 173 Such regulations "are kept in a ministry official's drawer, removed on one occasion, and left in the drawer on another." 174 Many governmental units in China are known for issuing "normative documents" - a hodgepodge of relatively informal decisions, notices, and provisions-that are not governed by the same publicity requirements that apply to other laws. ${ }^{175}$

Hidden laws often take the form of verbal directives. 176 Such directives may present as "administrative" notices that supplement or even contradict written laws. ${ }^{177}$ Or they may present as direct orders for judges to rule in a particular way-directives that would seem to subvert law rather than to constitute it. In studies of Russia, the latter is sometimes called "telephone law"178 or "telephone justice,"179 referring to "a practice by which outcomes of cases allegedly come from orders issued over the phone by those with political power rather than through the application of law." 180

Hidden laws reserve for authoritarian leaders a measure of flexibility and discretion. Indeed, "the control of privileged information is one of the crucial factors that allow those in power to retain their power."181 A key advantage of drawer regulations, for example, is that they may be "applied with an

173 Michael W. Gordon, Of Aspirations and Operations: The Governance of Multinational Enterprises by Third World Nations, 16 U. MIAMI INTER-AM. L. REV. 301, 333 (1984) (describing the use of such regulations in predemocratic Brazil); see also Animal Sci. Prods., Inc. v. China Nat'l Metals \& Mineral Imp. \& Exp. Corp., 702 F. Supp. 2d 320, 427 n.104 (D.N.J. 2010) (asserting that China is "still in the process of eradicating this mode of administering Chinese law"), vacated and remanded sub nom. Animal Sci. Prods., Inc. v. China Minmetals Corp., 654 F.3d 462 (3d Cir. 2011).

174 Gordon, supra, note 173 , at 333-34.

175 Chen, supra note 166 , at $44-46$ (noting that normative documents are not subject to Legislation Law publication requirements, though some local rules have progressively begun to regulate them).

176 See In re Vitamin C Antitrust Litig., 810 F. Supp. 2d 522, 550 (E.D.N.Y. 2011) (referencing an expert report on how "oral directives are an important component of Chinese regulatory law"), rev'd and remanded sub nom. Animal Sci. Prods., Inc. v. Hebei Welcome Pharm. Co., 837 F.3d 175 (2d Cir. 2016), vacated and remanded, 138 S. Ct. 1865 (2018).

177 See Chen, supra note 166, at 45 (describing the use of an unpublished oral "normative document" to raise the application fee of an auto import license from 10 yuan to 40,000 yuan). One scholar recounts a Russian official reprimanding his subordinate for administering his written instructions: "If I wanted you to do something, I would have called you," he said. TIMOTHY J. COLTON, YELTSIN: A LIFE 325 (2007).

178 Kathryn Hendley, 'Telephone Law' and the 'Rule of Law': The Russian Case, 1 HaGUE J. ON RULE L. 241, 241 (2009).

179 See Stephen Breyer, The Court AND the World 274 (2015); Alena Ledeneva, Telephone Justice in Russia, 24 POST-SOVIET AFF. 324, 324 (2008) ("telefonnoye pravo" in Russian).

180 Hendley, supra note 178 , at 241.

181 Darren C. Zook, Reforming North Korea: Law, Politics, and the Market Economy, 48 STAN. J. INT'L L. 131, 134 (2012). 
inconsistency permitted by the lack of public disclosure."182 Published laws, in contrast, lay bare rules that governments may wish to hide from the public, and risk future application to unforeseen parties or circumstances. Nonpublication can help autocrats preserve deniability, furthering the autocratic "virtue" of "obfuscation by design." 183

Another class of rules that might be thought of as "hidden law" is party law. Many authoritarian regimes are ruled by single parties that govern members (and nonmembers) through party policies and regulations. These rules do not usually purport to be positive law, and yet in many areas party policies are so fused with state law that any serious inquiry into foreign law may be incomplete without a discussion of what party rules require. ${ }^{184}$ Such rules can be written or unwritten, published or unpublished, but as a parallel, overlapping, and often overriding source of authority, 185 their existence can further complicate the modernist picture.

As with sham laws, norms or commands that lack the trappings of law can pose serious questions for American judges. When if ever should a court recognize an unwritten or unpublished prescript as law? Can oral commands be law? What about party rules? Is foreign law just what officials do? Or just what certain foreign authorities say? What if such authorities explicitly contradict what is written in the statute books? More broadly, how should a court deal generally with sources of law that may be unavailable or incomplete?

\section{c. Political "Courts"}

Just as authoritarian laws sometimes depart from their counterparts in modernist legal systems, so too can authoritarian courts. In such cases, judicial outcomes are determined not by a neutral application of specialized reasoning, but by the consideration of nonlegal factors shaped by political interests. ${ }^{186}$

182 Gordon, supra note 173 , at 334.

183 Zook, supra note 181 , at 134 .

184 See Berman, supra note 163 , at $56_{3}$ (observing the "serious problems in using [Soviet] materials" when "writers and courts are bound by Party policies which are not always explicitly stated"); Jiang Shigong, Written and Unwritten Constitutions: A New Approach to the Study of Constitutional Government in China, 36 MOD. CHINA 12, 26 (2010) ("[T]o understand the operation of constitutionalism in China, it is necessary to understand both the constitution of the PRC and the constitution of the CCP.").

185 See Anthony R. Dicks, Compartmentalized Law and Judicial Restraint: An Inductive View of Some Jurisdictional Barriers to Reform, 1995 CHINA Q. 82, 96-98 (listing cases in which Chinese Communist Party rules functionally prevailed over ordinary laws); Penelope Nicholson \& Nguyen Hung Quang, The Vietnamese Judiciary: The Politics of Appointment and Promotion, 14 PAC. RIM L. \& POL'Y J. 1, 4 (2005) (asserting that in the "conception of [the Vietnamese] law-based state, Party policy continues to be as influential as law").

186 See, e.g., CYNTHIA ESTLUND, A NEW DEAL FOR CHINA's WORKERS? 121 (2017) (describing how "political control of the judicial branch" has led to "lagging enforcement" in labor law). 
Authoritarians can influence judicial outcomes in several ways. The most direct strategy is to intervene in individual cases-a concept introduced earlier as "telephone justice." In practice, many authoritarian countries have substituted informal "telephone" interventions with permanent influence institutions, such as party cells or committees, which can convey not only specific instructions, but also broader expectations. ${ }^{187}$ Another favored tactic is to install or foster loyalists within the judiciary. 188 This can happen through subtle manipulations of appointment procedures, 189 or through more direct control of appointments, promotions, and discipline via party authorities, as in China. ${ }^{190}$ Until recently in Vietnam, every judicial candidate's application dossier had to include an "opinion letter from the Communist Party cell."191 Rulers new to power may also choose to convert judges into loyalists by rewarding favorable decisions with grants of new authorities. ${ }^{192}$ Even unaffiliated judges, reading the tea leaves, may rule to favor regime interests to further, or at least preserve, professional status. ${ }^{193}$ Other interventions are more structural. Autocrats sometimes manipulate jurisdiction by channeling sensitive matters into exceptional courts.194 On other occasions, governments

187 See Ledeneva, supra note 179, at 329 ("Virtually all Soviet judges were members of these party cells and were expected to implement the directives that the party apparatus communicated at party meetings."). Informal interventions continue to influence Russian adjudications. See Peter Solomon, Authoritarian Legality and Informal Practices: Judges, Lawyers and the State in Russia and China, 43 COMMUNIST \& POST-COMMUNIST STUD. 351,353-54 (2010) (describing also how judges in Russia are pressured to "respond to external pressures" if they want to receive discretionary perks or promotions or avoid disciplinary action).

188 See, e.g., Jennifer Widner \& Daniel Scher, Building Judicial Independence in Semi-Democracies: Uganda and Zimbabwe, in RULE BY LAW, supra note 145, at 235, 251 (describing how President Robert Mugabe of Zimbabwe expanded the Supreme Court to include pro-government judges).

189 See Ozan O. Varol, Stealth Authoritarianism, 100 IOWA L. REV. 1673, 1688 (2015) (recounting how Turkish "military leaders structured the appointments process to the [Turkish Constitutional] Court" to ensure that pro-military interests controlled selection).

190 See WANG, supra note 148, at 68-71 (explaining that the Party's informal rules surrounding the appointment and removal of judges undermine the formal rules developed by the legislature).

191 Nicholson \& Quang, supra note 185, at 14 (quoting Ministry of Justice \& Special People's Court Inter-Circular No. 05/TTLN, Guiding the Ordinance on People's Judges and Jurors, pt. III, item 2 (Oct. 15, 1993)).

192 See, e.g., Varol, supra note 189, at 1690 (noting how Russian Constitutional Court Chair Valery Zorkin's "support for the Putin government . . . regained the court many of its former authorities").

193 See Moustafa \& Ginsburg, supra note 145, at 14-15 (arguing that even "reform-minded judges" in authoritarian regimes "are acutely aware of their insecure position in the political system").

194 See Thomas Ginsburg, Judicial REview In NEW DEMOCRACIES: CONSTITUTIONAL COURTS IN ASIAN CASES 211-13 (2003) (noting how authoritarian President Park Chung-Hee of South Korea transferred constitutional review powers to a new committee under his control); Anthony W. Pereira, Of Judges and Generals: Security Courts under Authoritarian Regimes in Argentina, Brazil, and Chile, in RULE BY LAW, supra note 145, at 23, 55 (discussing how authoritarian regimes rely on "trustworthy" security courts); José J. Toharia, Judicial Independence in an Authoritarian Regime: The Case of Contemporary Spain, 9 LAW \& SOC'Y REV. 475, 486-95 (1975) (describing Spanish "special tribunals" having exclusive "jurisdiction over cases which are politically conflictive"). 
curtail jurisdiction entirely, ${ }^{195}$ or employ more direct forms of intimidation, such as arresting judges. ${ }^{196}$

Influence operations can fundamentally alter the nature of authoritarian courts. ${ }^{197}$ The modernist ideal of impartial justice assumes that judges decide legal disputes through a neutral application of specialized reasoning. Such reasoning does not have to be legal in a narrow sense of the word; common law courts will often explicitly consider policy, for example. But decisions that subordinate local rules of interpretation to the interests of a party or nonparty plainly violate impartiality.

How should American courts treat foreign judgments rendered under extrajudicial pressure? Should they still try to predict how a foreign court would rule in all cases, even those where foreign judges will likely be subject to political interference? How would American judges even know? Should they even try to know, or are considerations of expressivity and efficiency better served by simply assuming modernist impartiality in all cases? And if there is evidence of extralegal influence, are there conditions under which such influence itself ought to be treated as law?

\section{Bifurcated Legal Systems}

The preceding discussion may paint a rather bleak picture of authoritarian law. Sham constitutions, hidden laws, and political courts inspire little confidence that an American court can mentally transpose itself as a foreign court, or at least "conceive of itself performing a parallel function." 198 The reality, however, is that many authoritarian legal systems contain both modernist and nonmodernist features. Indeed some borderline autocracies, such as Singapore, evince modernist tendencies in all but a few areas. ${ }^{199}$ This more complete picture of authoritarian law can pose its own set of linedrawing problems for American courts.

195 See GINSBURG, supra note 194, at 135-36, 211-13 (describing jurisdiction-stripping in Taiwan and Korea); Keith Hand, Resolving Constitutional Disputes in Contemporary China, 7 E. ASIA L. REV. 51, 68-69, 86 (2012) (describing how authoritarian governments in China and Taiwan effectively wrested jurisdiction over constitutional claims away from the courts).

196 See, e.g., Widner \& Scher, supra note 188, at 252 (recounting how a judge on Zimbabwe's High Court was arrested after seeking to require a government minister to comply with a summons to appear on contempt charges).

197 The nonjudicial functions of some authoritarian courts are well documented. See, e.g., Rachel E. Stern, The Political Logic of China's New Environmental Courts, CHINA J., July 2014, at 53, 54 (listing several "judicial activities" besides dispute resolution, including "policy advocacy, education, and social control").

198 Slaughter, supra note 9, at 1947.

199 See RAJAH, supra note 148 , at 9 ("Singapore has selectively performed emasculated facets of the 'rule of law,' facets which lack the core capacity to limit state power."). 
Scholars sometimes describe authoritarian legal systems as "dualistic" or "bifurcated." ${ }^{200}$ In routine commercial, civil, and even criminal matters, bifurcated legal systems will largely conform to modernist principles: the laws will be mostly written, consistent, and clear, and they will be applied by reasonably neutral and competent jurists. Yet, in matters that are more politically consequential, written laws may yield to secret commands and otherwise autonomous judges may begin to resemble political agents. Russian law, for instance, is characterized by both progress in "meeting international standards" and active state efforts to "dilut[e] their effect and maintain[] control through informal practices." 201 Similarly, though Singapore's courts perennially top global rule-of-law charts, ${ }^{202}$ they almost invariably bend to the ruling party's priorities at key junctures. ${ }^{203}$ As for China, scholars have pointed to "bifurcations" along several fault lines: between civil law and criminal law ${ }^{204}$; between commercial law and noncommercial law ${ }^{205}$; and between wealthy urban courts and poorer rural courts. 206

On some level, dualistic legal systems are not new phenomena-even older, more brittle regimes "had some regularity when dealing with nonpoliticized cases." ${ }^{207}$ Where many modern authoritarian states distinguish themselves is in the sector-specific nature of the bifurcation, as well as the sheer magnitude of the gap between sectors. 208

200 See RACHEL E. STERN, ENVIRONMENTAL LITIGATION IN CHINA: A STUDY IN POLITICAL AMBIVALENCE 229 (2014) (explaining that "judicial performance" and "judicial independence" are two distinct factors at play in "bifurcated" legal systems); Hendley, supra note 178, at 260 (noting that in the Russian legal system there are "exceptional cases in which the outcomes are manipulated to serve the interests of the powerful" but "the vast majority of decisions . . . are made in accordance with the law").

201 Solomon, supra note 187 , at 352.

202 See, e.g., WORLD Justice PROJECT, WORLD JUSTICE PROJECT RULE OF LAW INDEX 20172018, at 16 (2018), https://worldjusticeproject.org/sites/default/files/documents/WJP_ROLI_2017-18_ Online-Edition_o.pdf [https://perma.cc/Q6XM-LPP7] (ranking Singapore thirteenth in the world for respect for the rule of law, above Japan, the United States, France, and Spain).

203 See Tushnet, supra note 23, at 403 ("Singapore's courts regularly uphold government actions that a more independent judiciary might question . . . .").

204 See William Hurst, RULing Before the LAW: THE POlitics OF LEgal REgimes IN CHINA AND INDONESIA 30-32 (2018) (contrasting the minimal interventionism of Chinese civil law with the "heavy[]" interventionism of "nonlegal actors" in Chinese criminal law").

205 See WANG, supra note 148, at 48-49, 158.

206 See Kwai Hang Ng \& Xin He, Embedded Courts: Judicial Decision-Making IN CHINA 6-14 (2017) (arguing that wealthier urban courts ("firm"-type courts) tend to value legal expertise, while poorer rural courts ("work-unit"-style courts) consider political factors more prominently).

207 Hendley, supra note 178, at 261 (describing the Russian legal system as "dualistic").

208 Another characteristic of some modern authoritarian countries is that their legal systems can vary in their commitment to legality over time. For example, the Hu Jintao era of Chinese law (2002-2012) has been characterized as a return to "populist" legality, a de-emphasizing of formal law, even a "turn against law," while the Xi Jinping era has been described as placing a greater emphasis on formal rational legality. Compare Liebman, Legal Reform, supra note 146, at 96 (describing a weakening of formal legal institutions and an increased reliance on out-of-court dispute resolution 
For American judges, such bifurcations present new problems. How do judges distinguish between features of authoritarian legal systems that actually adhere to modernism versus features that only do so superficially? Should foreign law interpretation itself be bifurcated, with more skepticism towards judicial decisions in noncommercial areas of law? Should foreign law evaluations be similarly bifurcated, with courts more willing to recognize judgments or dismiss for forum non conveniens in certain sectors of foreign law compared to others? Or are all of these complications instead the best argument for embracing modernist simplicity?

\section{A Caveat}

While one can generalize, as I have, about differences between authoritarian and liberal legality, no legal system perfectly conforms with the modernist ideal. All countries-regardless of regime type-deal to varying degrees with problems of poor implementation or judicial corruption.209 And while there are material differences between laws that are poorly implemented and "laws" that are actually sham-I explore this in detail below 210 - even liberal systems may depart from modernism in ways that feel authoritarian. Japanese judges, for example, can be highly deferential in politically sensitive case for fear of lower pay, less desirable rotations, and diminished prestige. ${ }^{211}$ In such cases, one might still describe specific practices as "authoritarian" because they involve punishments that the state has meted out to curb accountability institutions that would otherwise constrain state power. ${ }^{212}$ But of course Japan is not authoritarian, for the system as a whole is insufficiently committed to antiaccountability as to warrant that label. Authoritarian legal systems might

under Hu), and Carl F. Minzner, China's Turn Against Law, 59 AM. J. COMP. L. 935, 936-37, 951 (2011) (similar), with Zhang \& Ginsburg, supra note 150, at 3 (identifying an increased reliance on formal law and strengthening of legal institutions under Xi Jinping), and Jacques deLisle, Law in the China Model 2.o: Legality, Developmentalism and Leninism under Xi Jinping, J. CONTEMP. CHINA, Sept. 2016, at 68, 70 (describing a "limited" return to formal legality in the Xi era). This fluidity can also pose challenges for American judges. For example, many courts often conclude that China offers an adequate forum because other courts have in the past found the same. See supra note 72. Such reasoning falsely assumes that the quality of legal systems remains static over time.

209 See, e.g., Stratos Pahis, Note, Corruption in Our Courts: What It Looks Like and Where It Is Hidden, 118 YALE L.J. 1900, 1925-42 (2009) (analyzing a data set of discovered incidents of judicial bribery in the United States).

210 See infra subsection III.B.1.a.

211 See J. Mark Ramseyer \& Eric B. Rasmusen, Why Are Japanese Judges So Conservative in Politically Charged Cases? 95 AM. POL. SCI. REV. 331, 331-32, 334, 338-41 (2001) (concluding that judges who rule against the government face a "career penalty").

212 See supra Section I.A. 
therefore be thought of as crystallizing certain types of nonmodernist departures that nonauthoritarians can nonetheless evince. ${ }^{213}$

\section{Antiauthoritarian Bias}

I turn finally to a different source of interpretive difficulty: the tendency among some judges to impute false assumptions to a foreign legal system based on the mere fact of the country's authoritarianism. Though biases of this sort are hard to measure, their existence can further inhibit accurate interpretation.

Antiauthoritarianism is an arguably American value. The country was formed on the belief that a monarch's "absolute [t]yranny" violated natural law. ${ }^{214}$ Ideological and military struggles against fascism and communism have further cemented this self-concept. Consistent with this aspect of American identity, American jurists and law scholars have often applied antiauthoritarian concepts to foreign legal systems. Such frames encourage a view that autocracies are essentially lawless. As Teemu Ruskola explains in the context of Chinese law:

The United States has from its founding regarded its political values as exemplary, not just reflecting the emancipatory values of the Enlightenment on the European model but embodying them even better than Europe does, or once did. The American system of government is thus not merely one expression among others of the universal values of democratic rule-of-law but their paradigmatic instance - a model for others to emulate . . . . At the same time, insofar as China's legal tradition grows out of an enduring Oriental despotism, its political values are inherently suspect. Worse than simply unlegal, they are in effect antilegal..215

To illustrate, Ruskola points to the system of extraterritoriality established by American and other Western powers in China. From 1906 to 1943, extraterritorial jurisdiction was exercised by the United States Court for China, a federal district court initially headquartered in Shanghai. ${ }^{216}$ American leaders justified the court as a means of avoiding and perhaps reforming the "despotism that allegedly inhered in the very nature of Chinese law".217 (And yet, as Ruskola details, the Court itself was hardly a paragon of liberal legal virtue, applying laws that were "so ad hoc as to be lawless."218)

213 My gratitude to William Alford for pointing me beyond dichotomous thinking, both here and in general.

214 THE DECLARATION OF INDEPENDENCE para. 2 (1776).

215 TEEMU RusKola, LEgAL ORIENTALISM 9 (2013).

216 See id. at 157-85 (detailing the history of the U.S. Court for China, which exercised jurisdiction over U.S. citizens in China).

217 Id. at 162.

218 Id. 
Legal antiauthoritarianism took on a distinctly geopolitical flavor during the Cold War. Statutes described the Communist Party as "an authoritarian dictatorship within a republic." 219 Justices railed against the "travesty" of "Communist justice," likening it to a "reign of terror." 220 Judges invoked the "barbarity" of Chinese law to protest decisions that might "become a precedent on which future Dracos may feed to their absolutist and tyrannical content."221 In Zschernig v. Miller, the Supreme Court reprimanded probate courts for interfering with federal policies through "critici[zing] nations established on a more authoritarian basis than our own." 222 In one such case, an Oregon court disbelieved Czechoslovakian declarations on the ground that government declarations from "communist-controlled countries" were inherently suspect.223

Relatedly, judges have sometimes employed illiberal law as a rhetorical or interpretive aide, to understand American law with reference to what it is not. 224 They have invoked Russian "telephone justice" to highlight the importance of judicial independence. 225 They have criticized "[d]raconian" tax collection measures for "appear[ing] more appropriate to an authoritarian regime."226 And while intrusive searches would no doubt solve more crime, "as a number of authoritarian governments . . . have proved," such searches would "convert the authorities themselves from the solution into the problem, as the same authoritarian governments have likewise proved." 227

219 Communist Control Act of 1954, 50 U.S.C. $\S \S 841-844$ (2018); see also Black v. Cutter Labs., 278 P.2d 905, 912-14 (Cal. 1955) (detailing the legislative intent behind various statutes targeting the Communist movement).

220 Shaughnessy v. United States ex rel. Mezei, 345 U.S. 206, 226 (1953) (Jackson, J., dissenting) (writing on the key "differences . . . between authoritarian procedure and common law"). "I understand that people in authoritarian countries must obey arbitrary orders," Justice Black once wrote in dissent. Feiner v. New York, 340 U.S. 315, 328 (1951) (Black, J., dissenting). "I had hoped that there was no such duty in the United States." Id.

221 Commonwealth v. Koczwara, 155 A.2d 825, 832-33 (Pa. 1959) (Musmanno, J., dissenting).

222389 U.S. 429, 440 (1968); see also id. at 437 ("As one reads the Oregon decisions, it seems that foreign policy attitudes, the freezing or thawing of the 'cold war,' and the like are the real desiderata.").

223 Id. at 436 (quoting State ex rel. State Land Bd. v. Pekarek, 378 P.2d 734, 738 (Or. 1963)).

224 In constitutional law, this phenomenon is sometimes described as a "negative comparativism." David Fontana, Refined Comparativism in Constitutional Law, 49 UCLA L. REV. 539, $551 \&$ n.59 (2001) (listing examples).

225 See, e.g., Wersal v. Sexton, 674 F.3d 1010, 1034-35 (8th Cir. 2012) (Loken, J., concurring) ("Telephone justice . . . occurred when the party boss called judges and told them how to decide the outcome of a particular case. . . . When pervasive, this perception corrodes public trust in the courts." (quoting Stephen Breyer, Judicial Independence: Remarks by Justice Breyer, 95 GEO. L.J. 903, 904-05 (2007))).

226 Fawber v. Dauphin Cty. Tax Claim Bureau, 44 Pa. D. \& C.3d 13, 21 (Pa. C.P. Dauphin Cty. 1987).

227 Ex parte Warren, 783 So. 2d 86, 96 (Ala. 2000) (Johnstone, J., concurring); see also Snider v. State, 501 So. 2d 609, 610 (1986) (Fla. Dist. Ct. App. 1986) (Glickstein, J., dissenting) (arguing that, to "residents of the numerous totalitarian and authoritarian states of our day," occasionally "let[ting] an offender go . . . is not a great price to pay" to avoid intrusive searches). 
The accounts above raise the possibility that antiauthoritarian biases could distort judicial interpretations of foreign laws. The concern, to be clear, is not that judges may accurately identify "aberrational" features of authoritarian law; I too have highlighted many such features above. The concern rather is that judges may make false assumptions about a foreign legal system due to the mere fact of its authoritarianism. They may sweepingly say, as Judge Posner once did, that "little about Chinese law is certain," when in fact there is a fair amount of regularity in some areas of Chinese law.228 Or they may rely upon general assumptions about autocracy to refuse a forum non conveniens motion or deny an asylum claim despite a lack of specific evidence. ${ }^{229}$ " $[A]$ priori views about how authoritarian regimes conduct themselves are no substitute for evidence," the Seventh Circuit once warned in an immigration appeal.230 This is "a point we have made repeatedly, but which has yet to sink in."231

To the many interpretive questions posed earlier, then, I would add a few more. How can courts realistically check antiauthoritarian biases if they exist? Is neutrality an achievable ideal? Or, conversely, is it even desirable that courts police such biases at all? Might treating all authoritarian laws as something less than "law," as Slaughter once advocated, instead promote other normative ends in law and international society? More broadly, should courts be more mindful that any declaration they make about law, even foreign law, has expressive and normative value? American courts are only just beginning to grapple with questions of this nature.

\section{FORMAL AND FUNCTIONAL APPROACHES TO AUTHORITARIAN LAW}

American judges have approached authoritarian legal systems from two basic vantage points. One method, which might be thought of as a kind of formalism, focuses on the written meaning of only those prescripts that correspond to familiar structures in modernist legal systems, primarily published statutes. A second method stresses context and function, giving effect to whatever may be locally regarded as law, even if such laws grate

228 Xue Juan Chen v. Holder, 737 F.3d 1084, 1086 (7th Cir. 2013) ("[L]ittle about Chinese law is certain, because China does not have the 'rule of law' as understood in our legal system . . . .").

229 See, e.g., Pyrenee Ltd. v. Wocom Commodities Ltd., 984 F. Supp. 1148, 1163 (N.D. Ill. 1997) (criticizing a District of Massachusetts case for "refusing dismissal to Hong Kong [prior to reversion] based solely on what appears to be judicial hysteria").

230 Banks v. Gonzales, 453 F.3d 449, 453 (7th Cir. 2006) (vacating denial of Liberian asylum claim).

231 Id. at 453-54 (collecting cases); see also Secaida-Rosales v. INS, 331 F.3d 297, 309 (2d Cir. 2003) (referring negatively to an immigration judge who based his implausibility finding on "his own unsupported opinion as to how an authoritarian government operates" (quoting Gao v. Ashcroft, 299 F.3d 266, 278 (3d Cir. 2002))). 
against the prefabricated molds of modernist legality. Most judgments tend towards formalism or functionalism; few embody them in their purest forms.

Formalism has heuristic advantages. It is easier, less resource-intensive, and can still get autocratic law "right" much of the time. It also has expressive value, enabling jurists to shape norms about the rule of law. But it can often misstate foreign law when local practices or concepts of law are not reflected in familiar structures. Functionalism's heightened accuracy, on the other hand, can require independent research or party-sponsored experts, neither of which are available in every case. Nor is functionalism always more helpful than formalism, given the bifurcated nature of many autocratic legal systems and the adversarial nature of expert testimony. And taken too far, functionalism can erode public norms about what "law" requires.

\section{A. Formalism and Functionalism}

I begin with an exposition of formalism and functionalism as methods of interpretation. Although versions of each approach can be applied to foreign law generally, ${ }^{232}$ I conceive of them here as ideal-type methodologies tailored to answering questions raised in the distinct authoritarian law setting. After explaining each theory, I discuss two leading district court cases that exemplify each approach.

\section{Formalism}

The hallmark of formalist interpretation is a scrupulous observation of legal formality. A formalist jurist will search for legal structures and institutions that correspond in form to her own and treat them as if they were broadly similar to her own. Such an approach requires an uncompromising commitment to modernist legality and a willingness to ignore evidence of deviations or bifurcations commonly found in illiberal legal systems.

In its purest form, formalism would treat as "law" all traditional sources of written laws within the modernist framework-constitutions, statutes, regulations, and, as relevant, judicial decisions. The fact that a legal document, even a constitution, may be unenforced or underenforced would be interpretively irrelevant. So long as the document was promulgated following commonly recognized procedures and bears the other hallmarks of positive state law, it is "law" for a formalist judge. Formalists would for similar reasons

232 Even when construing "liberal" laws, the choice between formalism and functionalism can yield varying interpretations. But in the authoritarian law setting, the formal-functional divide is both more salient and more interesting. The nonmodernist departures characteristic of authoritarian legal systems will frequently force a hard choice between formalism's strict assumptions about legality and functionalism's more contextual inquiry. 
be disinclined to apply "hidden" laws that have no formal correspondences in modernist legality. Nor would they look "behind" a judicial decision, or countenance evidence of a "bifurcated" legal system, preserving for themselves a useful fiction of uniform good-faith adjudication.

Formalism in the sense used here bears a family resemblance to other formalisms in American law. Like some strains of American legal formalism, formalism sees interpretation primarily as an exercise in deductive logic, divorced from considerations of policy or society. 233 Formalism here also shares some of the features of constitutional "formalism."234 By weighing text over purpose, bright-line categories over more contextualized inquiries, formalism here evokes constitutional formalism's relatively rigid notions of structure.235

\section{Functionalism}

The second major approach to autocratic law stresses function over form. Functionalists take a more expansive and flexible view of legality, focusing on how rules and norms operate on the ground and within their specific political, social, and cultural context. Instead of presuming similarity, functionalists recognize difference and give effect to such difference, even to "hidden" laws, for example, so long as there is adequate evidence that the disparate structures function as law or are regarded locally as law. But "sham" laws, whether constitutions, statutes, or regulations, can be ignored if context establishes that they are practically or functionally nonlegal, regardless of how much they conform to accepted formalities.

Functionalism as used here is closely related to functionalist methodologies in comparative law. Comparative law functionalists assume that "the legal system of every society faces essentially the same problems," which are addressed through "quite different means though very often with

233 See Morton J. Horwitz, The Rise of American Legal Formalism, 19 AM. J. LEGAL HIST. 251, 256 (1975) ("[Legal formalism] conceive[s] of law not as a malleable instrument of . . . desires and interests, but as a fixed and inexorable system of logically deducible rules."); Richard A. Posner, Legal Formalism, Legal Realism, and the Interpretation of Statutes and the Constitution, 37 CASE W. RES. L. REV. 179, 181 (1986) ("I want [formalism] to mean the use of deductive logic to derive the outcome of a case from premises accepted as authoritative."). But see Brian Leiter, Legal Formalism and Legal Realism: What is the Issue?, 16 LEGAL THEORY 111, 111 (2010) (criticizing the fact that "'formalism' is sometimes associated with the idea that judicial decision-making involves nothing more than mechanical deduction on the model of the syllogism").

234 John F. Manning, Separation of Powers as Ordinary Interpretation, 124 HARV. L. REV. 1939, 1958 (2011) (characterizing formalism in part as "adher[ance] to the conventional meaning of the text instead of resorting to the broad purposes underlying it"); see also Peter L. Strauss, Formal and Functional Approaches to Separation of Powers Questions-A Foolish Inconsistency?, 72 CORNELL L. REV. 488, 512 (1987) (contrasting formalism's "technical positivism" with functionalism's "policy analysis").

235 See Manning, supra note 234, at 1950 (describing formalism as favoring rules over standards and text over purpose). 
similar results." 236 Their goal is to understand these means in the light of their functional purposes, to place law within "the context of the institutional, economic and cultural pillars of each society." 237 The resulting inquiry is necessarily fact-driven, focusing "not on rules but on their effects, not on doctrinal structures and arguments, but on events." 238 Functionalism here shares many of these demythologizing assumptions. By focusing on law in action over law as written, it is redolent of Roscoe Pound's sociological jurisprudence, ${ }^{239}$ and some tenets of legal realism: Justice Holmes famously defined law as "the prophecies of what the courts will do in fact, and nothing more pretentious." 240

\section{Leading Cases: The Chinese Export Cases}

To illustrate formalism and functionalism in practice, I describe below two cases that evince some of the salient differences between them: In re Vitamin C Antitrust Litigation 241 ("the Vitamins case") and Animal Science Products, Inc. v. China National Metals \& Minerals Import E Export Corp. ("the Magnesite case"). 242 The decisions are natural comparisons. They involve similar facts, similar claims, and even the same lead plaintiff. And yet on the question of how to treat foreign laws that deviate from "law" as commonly understood, they exemplify contrasting approaches.

236 KonRad ZWEIGERT \& HEIN KÖTZ, INTROdUCTION TO COMPARATIVE LAW 31 (2d ed. 1987).

237 Annelise Riles, Wigmore's Treasure Box: Comparative Law in the Era of Information, 40 HARV. INT'L. L.J. 221, 228 (1999); see also Max Rheinstein, Teaching Comparative Law, 5 U. CHI. L. REV. 615, 617-18 (1938) ("What function does [law] serve in present society?").

238 Ralf Michaels, The Functional Method of Comparative Law, in THE OXFORD HANDBOOK OF COMPARATIVE LAW 339, 342 (Mathias Reimann \& Reinhard Zimmermann eds., 2006).

239 See generally Roscoe Pound, The Scope and Purpose of Sociological Jurisprudence (pts. 1 \& 2), 24 HARV. L. REV. 591 (1911), 25 HARV. L. REV. 140 (1911); Roscoe Pound, Law in Books and Law in Action, 44 AM. L. REV. 12 (1910); see also James Gardner, The Sociological Jurisprudence of Roscoe Pound, 7 VILL. L. REV. 1, 9 (1961) (describing sociological jurisprudence's "attitude" as "essentially functional").

240 Oliver Wendell Holmes, Jr., The Path of the Law, 10 HARV. L. REV. 457, 461 (1897). Functionalists can also be legal pluralists, especially if there is evidence that foreign courts also give effect to normative orders outside of centralist positive state law. See, e.g., John Griffiths, What is Legal Pluralism?, 24 J. LEGAL PLURALISM \& UNOFFICIAL L. 1, 5 (1986) (noting that colonial and postcolonial countries often have pluralistic legal systems that incorporate "pre-existing customary law"); William Twining, Normative and Legal Pluralism: A Global Perspective, 20 DUKE J. COMP. \& INT'L L. 473, 489-93 (2010) (describing the role of normative orders in cases arising in Sudan, Kenya, and Brazil).

241810 F. Supp. 2d 522 (E.D.N.Y. 2011), rev'd and remanded sub nom. Animal Sci. Prods., Inc. v. Hebei Welcome Pharm. Co., 837 F.3d 175 (2d Cir. 2016), vacated and remanded, 138 S. Ct. 1865 (2018).

242702 F. Supp. $2 \mathrm{~d} 320$ (D.N.J. 2010), vacated and remanded sub nom. Animal Sci. Prods., Inc. v. China Minmetals Corp., 654 F.3d 462 (3d Cir. 2011). 


\section{a. The Vitamins Case-A Formalist Approach}

Begin with the Vitamins case, the more prominent of the two for having reached the Supreme Court in 2018.243 The plaintiffs, American companies, brought a putative class action against several Chinese vitamin C manufacturers for allegedly engaging in an illegal cartel.244 The defendants asserted a foreign sovereign compulsion defense, applicable when a foreign defendant is required by their home law to engage in activities that violate American law. 245 The question was whether Chinese law in fact compelled vitamin $\mathrm{C}$ exporters to fix prices and output. 246

The defendants were members of the Chamber of Commerce of Medicines and Health Products Imports and Exporters, one of a number of Ministry of Commerce-supervised entities responsible for industry "coordination" in China.247 Under a 1997 Notice, a Chamber Subcommittee composed of all vitamin $\mathrm{C}$ exporters had been charged with awarding licenses only to companies that followed certain price and quantity restrictions. ${ }^{248}$ Following China's entry into the World Trade Organization (WTO), this regime was replaced with a "Price Verification and Chop" (PVC) system, under which the Chamber conveyed its coordinated prices and quantities to Customs, which was then expected to limit export only to contracts that had received a "chop" from the Chamber. ${ }^{249}$ A revised Subcommittee Charter described the committee as composed of "self-disciplinary industry organization[s] jointly established on a voluntary basis." 250

Judge Cogan began his analysis by acknowledging the unusual nature of the task before him:

At the outset, I am compelled to note that the Chinese law and regulatory regime that defendants rely on is something of a departure from the concept of "law" as we know it in this country . . . . [D]efendants' own expert asserts that oral directives are an important component of Chinese regulatory law .... [I]n some circumstances, asserting a claim of compulsion under a

243 Animal Sci. Prods., Inc. v. Hebei Welcome Pharm. Co., 138 S. Ct. 1865 (2018).

244 Vitamin C Litig., 810 F. Supp. 2d at 524.

245 See id. at 544-45. In Hartford Fire Ins. Co. v. California, the Supreme Court held that international comity counseled against exercising extraterritorial antitrust jurisdiction when there is a true conflict between U.S. and foreign law. 509 U.S. 764, 798 (1993). The defense reflects considerations of comity, fairness, and constitutional structure. See Vitamin C Litig., 810 F. Supp. $2 \mathrm{~d}$ at 524 .

$246 \mathrm{Id}$. at 524-25.

247 See Vitamin C Litig., 810 F. Supp. 2d at 526-27.

248 Id.

$249 \mathrm{Id}$. at 527-28.

$250 \mathrm{Id}$. at $530-31$. 
foreign regime that so differs from our own concept of law can be akin to trying to fit a round peg into a square hole. ${ }^{251}$

These differences notwithstanding, Judge Cogan resolved the case on the basis of formal written law. The key provision, in his view, was language in a 2002 notice permitting the Chamber to "suspend export price review." $252 \mathrm{He}$ took the plain language of that provision "as granting defendants the unilateral authority to suspend verification and chop." 253 And because a suspension power implied no compulsion, that provision "standing alone" was "sufficient reason to deny summary judgment."254

Judge Cogan cited other formalist grounds for his finding, relying on "the more traditional sources of foreign law-primarily the governmental directives themselves as well as the charter documents of the Subcommittee and the Chamber." 255 He argued, for instance, that "nothing on the face of the governmental directives" appeared to require that companies comply with output restrictions to receive a chop.256 In a later section, he relied on "the plain language" of a 2002 notice to discount an "ambiguous provision." $257 \mathrm{He}$ also refused to credit a Ministry of Commerce filing on the ground that "the plain language of the governmental directive" appeared to "contradict[] the position taken by the Ministry." 258 Later, while acknowledging that "selfdiscipline" meant something specific to the Chinese regulatory context, Judge Cogan nevertheless concluded that the term could not indicate coercion: "[A]s the term 'self-discipline' suggests on its face," he wrote, "defendants were engaged in consensual cartelization."259

\section{b. The Magnesite Case-A Functionalist Approach}

The Magnesite decision gave greater weight to functional considerations. Plaintiffs there, led by one of the same parties in the Vitamins case, alleged that seventeen Chinese manufacturers of magnesite-based products pursued "illegal horizontal agreements" to fix prices in violation of the Sherman Act. 260 As in the Vitamins case, the Magnesite defendants argued for

251 Id. at $55^{\circ}$ (emphasis added).

252 Id. at 553 .

$253 \mathrm{Id}$.

254 Id. at 554 .

255 Id. at 550 (emphasis added).

$256 I d$. at 554 (emphasis added).

257 Id. at 555 .

$258 \mathrm{Id}$. at 542 .

$259 I d$. at 566 (emphasis added).

260 See Animal Sci. Prods., Inc. v. China Nat'l Metals \& Minerals Imp. \& Exp. Corp., 702 F. Supp. 2d 320, 329 (D.N.J. 2010), vacated and remanded sub nom. Animal Sci. Prods., Inc. v. China Minmetals Corp., 654 F.3d 462 (3d Cir. 2011). 
abstention on the ground that Chinese law had mandated their price fixing. ${ }^{261}$ The regulatory regime for magnesite products was strikingly similar to the one regulating vitamin $\mathrm{C}$-the defendants were also members of a Ministry of Commerce-supervised chamber; 262 the Chamber was responsible for coordinating industry-wide prices; 263 and the Chamber had at various points described itself as engaging in "self-discipline." 264

Like Judge Cogan, Judge Brown struggled with how to understand nonmodernist features of Chinese law. Issues of "unwritten law," "drawer regulations," and unpublished law raised similar issues of un-legality. ${ }^{265} \mathrm{But}$ unlike Judge Cogan, Judge Brown privileged function over form.

On what constituted "law," for instance, he eschewed the requirement of "writtenness": "The Court finds Plaintiffs' position that in order to be 'real law, a mandate must be reduced to a . . . written statement issued by a government[] unduly condescending toward foreign legal regimes structured differently from the system used in the United States, Europe, or akin."266 "Likewise," he said, "it cannot be said that a prescript is not 'real law,' and its violation would not result in repercussions if the prescript is merely set forth in terms of a broad caution: not every type of prescript enacted by every legal regime in the world is open to the constitutional challenge of vagueness."267 And, in response to plaintiffs' contention that a major regulation did not explicitly authorize price setting, Judge Brown cited back to his discussion of foreign law: "[M]any provisions are treated as 'law' regardless of the fact that the delegated authority of the authors is not-or cannot-be established."268

Judge Brown was attentive to problems of bias in other areas. In assessing compulsion, he argued that it was "wholly illogical to factor in . . . the sociopolitical and cultural perceptions of a foreigner . . ." $269 \mathrm{He}$ seemed particularly skeptical of relying on the plain English meaning of translated written authorities: "[I]t would be an error to automatically qualify a foreign prescript as non-mandatory on the grounds that a literal translation [of the] prescript has non-compulsory connotations to an American ear in light of the socio-political and cultural peculiarities of United States life." 270 While the Chamber's use of the term "self-discipline" may connote "complete discretion"

\footnotetext{
261 Id. at 330.

262 Id. at 395 .

263 Id. at 396-97.

264 Id. at 436.

265 Id. at 427 n.104.

266 Id. at 424 n.100.

267 Id at 424.

268 Id. at $446 \&$ n.132.

$269 \mathrm{Id}$. at 422.

$270 \mathrm{Id}$. at $425 \&$ n.102.
} 
"to a Western ear," he said, the "Chinese meaning" of the term "suggests a disguised form of strict government compulsion."271

Judge Brown ultimately held that Chinese law compelled defendants' conduct. ${ }^{272}$ It is true, he conceded, that compulsion did not derive from "a simple issuance of a single legal mandate that remained continuously operative . . . ."273 Instead, there was in place a "legal 'regime' that employed various regulatory mechanisms producing a composite effect of a neverceasing correlation between the minimum price requirement and punitive measures for non-compliance with it." 274 China's entry into the WTO did not change the basic nature of this regime-"[b]oth the gist and the continuum of such regime was, seemingly, left unaffected" by it.275

\section{c. Comparing the Compulsion Cases}

The Vitamins and Magnesite Cases are not perfect exemplars of formalism and functionalism. Judge Cogan also examined the factual record to understand "how Chinese law was enforced and applied,"276 while Judge Brown at one point questioned how useful it would be to examine the degree of legal underenforcement in practice. 277 Still, the methodological differences are stark, well illustrating the two leading approaches to the problems of authoritarian law.

Judge Cogan followed the plain meaning of published authorities, vindicating the plaintiffs' strategy to stress only the "plain language" of Ministry directives and Chamber documents. ${ }^{278}$ The defendants, in contrast, relied upon testimony from a native expert named Shen Sibao,279 as well as a Ministry of Commerce filing purporting to explain the regulatory scheme's function in practice. ${ }^{280}$ Judge Cogan did not credit much of Shen's

271 Id. at $436 \&$ n.117.

272 Id. at 449 .

$273 \mathrm{Id}$.

$274 \mathrm{Id}$.

275 Id.

276 See In re Vitamin C Litig., 810 F. Supp. 2d 522, 550, 564-67 (E.D.N.Y. 2011), rev'd and remanded sub nom. Animal Sci. Prods., Inc. v. Hebei Welcome Pharm. Co., 837 F.3d 175 (2d Cir. 2016), vacated and remanded, 138 S. Ct. 1865 (2018).

277 See China Nat'l Metals, 702 F. Supp. 2d at 423 ("The fact that a certain . . . entity succeeds at avoiding negative repercussions, cannot be read as a sign that the legal regime is not compelling ....."). The two judges also evinced somewhat different understandings of "compulsion." See Vitamin C Litig., 810 F. Supp. 2d at 545.

$278 \mathrm{Id}$. at 526 n.5, 542.

279 Professor Shen is a professor and the former dean of the law school at the University of International Business and Economics in Beijing, China. Report of Professor Shen Sibao, supra note 172 , at 134 .

280 Vitamin C Litig., 810 F. Supp. 2d at 526. 
testimony, 281 nor did he defer to the Chinese government's explanation of its own laws. ${ }^{282}$ His main analysis was literally titled, "Interpretation of Chinese Law Based on the Traditional Sources of Foreign Law."283

Judge Brown, on the other hand, took pains to decenter his legal presuppositions. His approach is reminiscent of Günter Frankenberg's view that "the dialectic of learning" foreign law requires both "distancing" and "differencing." 284 Distancing is "an attempt to break away from firmly held beliefs and settled knowledge"; differencing "calls into question the neutrality and universality of all criteria . . . ."285 Judge Brown's call to shed the "sociopolitical and cultural perceptions of a foreigner" was an instance of distancing, of "de-center[ing] [one's] world-view" and striving for "objectivity." $286 \mathrm{His}$ relatively expansive conception of "law" itself was an exercise in differencing, an effort not to "confus[e] the present content of (Western) ideas and concepts [about law] with the criteria of a universal truth and logic."287 It is the latter activity, of differencing, that authoritarian law is most likely to elicit in functionalist interpretations.

\section{d. Authoritarian Credibility}

Judge Cogan's refusal to defer to the Ministry of Commerce filing raises a related issue of authoritarian credibility. Are litigation filings inherently more suspect when they are submitted by an illiberal government? The question, as posed, might seem unfair, a violation of modernist norms of impartiality and a tradition of international comity in American law.288 But as the Vitamins case progressed, courts began to grapple with a related question: how much deference is owed to a foreign government's filings concerning its own law? On appeal, the Second Circuit held that courts are "bound to defer" to all

281 See, e.g., id. at 551 n.39 (describing Professor Shen's definition of "self-discipline" as "circular and unhelpful").

282 Id. at $55^{1-52 .}$

$283 \mathrm{Id}$. at 553 (emphasis added).

284 Günter Frankenberg, 26 HARV. INT’L L.J. 411, 414 (1985).

$285 \mathrm{Id}$.

286 Animal Sci. Prods., Inc. v. China Nat'l Metals \& Minerals Imp. \& Exp. Corp., 702 F. Supp. $2 \mathrm{~d} 320,422$ (D.N.J. 2010), vacated and remanded sub nom. Animal Sci. Prods., Inc. v. China Minmetals Corp., 654 F.3d 462 (3d Cir. 2011); Frankenberg, supra note 284.

287 Frankenberg, supra note 284.

288 See, e.g., Hilton v. Guyot, 159 U.S. 113, 163-64 (1895) (defining "comity" as "the recognition which one nation allows within its territory to the . . . acts of another nation, having due regard both to international duty and convenience, and to the rights of its own citizens, or of other persons who are under the protection of its laws"); see also Societe Nationale Industrielle Aerospatiale v. U.S. Dist. Court for the S. Dist. of Iowa, 482 U.S. 522, $543 \&$ n.27 (1987) ("Comity refers to the spirit of cooperation in which a domestic tribunal approaches the resolution of cases touching the laws and interests of other sovereign states."). 
reasonable constructions of law proffered by foreign governments. ${ }^{289}$ The Supreme Court disagreed, ${ }^{290}$ providing guidance that - though not targeted at autocratic countries explicitly-seemed tailored to yield more skeptical treatment of authoritarian government filings.

When the Supreme Court granted certioriari, few precedents had addressed the question presented. In United States v. Pink, the Court had credited as "conclusive" a Russian declaration of its own law.291 Lower courts split as to whether Pink mandated outright or merely substantial deference to submissions from foreign governments. 292 Comity and comparative expertise counseled in favor of deference, but the litigation setting raised a legitimate concern that foreign governments might misrepresent their law to protect national interests.

The Vitamins case brought this tension into sharp relief. In 2002, China had represented to the WTO that it no longer engaged in "export administration . . . of vitamin C," a claim that appeared at odds with its federal filings asserting that Chinese law compelled price fixing. ${ }^{293}$

Citing this inconsistency, 294 the Supreme Court held that comity demanded only "respectful consideration" of a foreign sovereign's filings. 295 "Conflicting statements" or those made "in the context of litigation," it explained, may be grounds for more "caution." 296 As for the "appropriate weight" to accord a given foreign interpretation, the Court continued, several factors stood out: "the statement's clarity, thoroughness and support; its context and purpose; the transparency of the foreign legal system; the role and

289 Animal Sci. Prods., Inc. v. Hebei Welcome Pharm. Co., 837 F.3d 175, 189 (2d Cir. 2016), vacated and remanded, 138 S. Ct. 1865 (2018).

290 Animal Sci. Prods., 138 S. Ct. at 1869.

291 United States v. Pink, 315 U.S. 203, 220 (1942). In Pink, the foreign declaration was obtained by the American government through "diplomatic channels." Id. at 218 .

292 Compare D'Angelo v. Petroleos Mexicanos, 422 F. Supp. 1280, 1284 (D. Del. 1976) ("The principle of Pink requires this Court to accept the opinion of the attorney general of Mexico as an official declaration by that government . . . ."), and Delgado v. Shell Oil Co., 89o F. Supp. 1324, 1363 (S.D. Tex. 1995) ("Plaintiffs argue that this opinion [from the attorney general of the Philippines] is conclusive as to the scope and effect of the law of the Philippines."), with Vitamin C Litig., 810 F. Supp. 2d at 540-42 (concluding that, under Pink and its progeny, "a foreign government's statement is not entitled to absolute or complete deference in all circumstances"), and Karaha Bodas Co. v. Pertamina, 313 F.3d 70, 92 (2d Cir. 2002) ("Where a choice between two interpretations of ambiguous foreign law rests finely balanced, the support of a foreign sovereign for one interpretation furnishes legitimate assistance in the resolution of interpretive dilemmas.").

293 Vitamin C Litig., 810 F. Supp. 2d at 552. The Ministry sought to explain this inconsistency away by arguing that WTO statement referred to the introduction of the 2002 Price Verification and Chop scheme. See Transcript of Oral Argument at 41, Animal Sci. Prods., 138 S. Ct. 1865 (No. 161220) ("In 2002, we adopted the PVC method . . . . And that's the approach that we took. That's what we said to the WTO.”).

294 Animal Sci. Prods., 138 S. Ct. at 1871, 1873-74.

295 Id. at 1874 .

296 Id. at 1873 
authority of the entity or official offering the statement; and the statement's consistency with the foreign government's past positions." 297

Taken together, these factors are likely to disproportionately impact how courts treat submissions from authoritarian countries. A test that looks to the "transparency" of a foreign legal system will naturally yield less deference for countries arranged along autocratic lines. ${ }^{298}$ The reference to non"transparency" might even be read as a euphemism for illiberalism. Further, a test that probes a "statement's consistency" with a foreign government's prior pronouncements will tend especially towards surfacing instances of authoritarian prevarication. As above explained, autocrats have a track record of embracing or denying legality as it suits them, deploying "laws" that may be hidden or sham. A regime that uses law selectively at home is probably more likely to do so in litigation abroad.299 All to say, the Supreme Court's deference regime sensibly captures concerns driven, at least in part, by authoritarian practices.

\section{B. Formal and Functional Approaches Compared}

The choice between formalism and functionalism implicates several competing values. Formalism offers compelling heuristic and expressive advantages, but its rote application can yield overnormalizing misstatements of foreign law. Functionalism is generally more "accurate," but it can also be costly, impractical and-taken too far-potentially violative of basic legal norms. As neither method is a panacea, judges should instead tailor method to context, balancing formalism's heuristic usefulness against functionalism's contextual advantages.

\section{On Accuracy}

As noted above, Rule 44.1 governs foreign law determinations in federal court. Its most important policy goal is to promote accurate interpretations of foreign law. Prior to the Rule's enactment, courts applied a fact-based approach to foreign law $-\mathrm{a}$ framework that tended to exclude relevant aids to

297 Id. at $1873-74$ (emphasis added).

298 The Court did not specify in which direction the "transparency" factor should cut. Lack of transparency may mean a foreign sovereign can more easily "game" the law to support its position, but it could also be a reason to defer to a foreign sovereign on grounds of expertise. Context, however, suggests the former.

299 Of course liberal countries can also be criticized for "instrumentalizing" or selectively ignoring law, particularly international law. See, e.g., Anu Bradford \& Eric A. Posner, Universal Exceptionalism in International Law, 52 HARV. INT'L L.J. 1, 6 (2011) (arguing that many if not all countries, including the United States and those within the European Union, at times evince selfinterested and exceptional approaches to international law). 
interpretation for violating technical rules of admissibility. 300 Rule 44.1 did away with this model. One of its inherent policies is that "whenever possible issues of foreign law should be resolved ... on the basis of a full presentation and evaluation of the available materials." 301 Judges are thus "obliged to take an active role in the process of ascertaining foreign law." 302 While they are not required to engage in private research, they are encouraged to do so when appropriate. ${ }^{303}$

Though accuracy is one of the Rule's cardinal policies, the Rule does not define the term. What does it mean to get foreign law "right"? The answer, I contend, should vary with context.

In one category of cases, judges must apply foreign law as a binding rule to the parties before her. In this setting, courts generally follow the "basic prescriptive principle" that "foreign law must be applied as it would be by the courts of the foreign jurisdiction." 304 This "predictive" rule has an analog in federal interpretation of state law. Under Erie, federal courts sitting in diversity must interpret state law as would that state's highest court.305 The predictive rule is well suited to the conflicts context, in which two parties, for example, might have contracted for a specific country's law to apply. It would undermine basic notions of harmony and consistency if Saudi law applied differently in Saudi Arabia than in Chicago. 306

In other cases involving foreign law, the aim is to ascertain foreign law as evidence of foreign practice. An asylum judge may ask whether a family planning law subjects violators to forced abortions, but only as a data point in assessing whether forced abortions are being perpetrated in fact. 307 Similarly, a judge contemplating whether to dismiss for forum non conveniens naturally cares about whether the written laws of the alternative

300 See Alexander, supra note 8, at 605-08 (describing the "sudden death" effect of the common law fact-based approach, where failure to prove foreign law "often resulted in immediate dismissal of the claim based upon a foreign law"); Brown, supra note 8, at 181-82 (describing how "the proper foreign law was often excluded from consideration by the party's inability to put foreign law materials in a format that would satisfy the technical rules of admissibility": specifically, "authentication, best evidence, and hearsay"); Miller, supra note 8, at 620-24 (noting that the fact-based approach was so burdensome "that it actually exacerbated the difficulties inherent in proving foreign law").

301 9A Charles Alan Wright \& ARThur R. Miller, Federal Practice and PROCEDURE $\S 2444$ (3d ed. 2008, rev. 2020).

302 Id.

303 See id. Some judges believe that "a court has the affirmative obligation to seek out the applicable foreign law whether the parties have established that law or not." Miner, supra note 8, at 583 .

304 Alexander, supra note 8 , at 630 . Most countries apply this principle. See NISHITANI, supra note 8 , at 31 (discussing how in most major jurisdictions foreign law is "interpreted and applied . . . in the same manner that a judge in that country would-to achieve international harmony and respect the parties' interest"). Consistency can, among other things, mitigate the risk of forum shopping.

305 See, e.g. , Stuart v. Colo. Interstate Gas Co., 271 F.3d 1221, 1228 (10th Cir. 2001) (stating that federal courts must "predict how [the state's] highest court would rule").

306 See NISHITANI, supra note 8, at 31.

307 See 8 U.S.C. $\S 1101(a)(42)(B)(2018)$. 
forum provide an adequate remedy, but she is (or at least, should be) more interested in whether local courts actually provide such remedies in practice. ${ }^{308}$ It would subvert the policies of dismissal to send a suit abroad based on a sham law. In cases such as these, "accuracy" is not just a prediction of how courts might rule on a question of law, but an honest appraisal of what has happened, or what may happen, on the ground.

While concepts of accuracy can vary between cases, functional approaches to interpretation generally surpass formal approaches in getting the law "right." ${ }^{09}$ This is especially true in the latter category of cases, which is explicitly oriented towards uncovering law as evidence of practice. But functionalism is also well-suited to traditional conflicts scenarios governed by the predictive rule. All would agree that standing in the shoes of a foreign jurist is an inherently contextual exercise.

\section{a. Qualifying the Predictive Rule}

In the authoritarian setting, however, the predictive rule requires some qualification. Taken literally, that rule requires courts to rule as a foreign court would rule. But because illiberal courts are often subject to regime pressure, one might wonder whether, or how, functionalist predictions might account for this possibility.

Consider the following hypothetical. An American court must decide whether one of China's champion technology companies violated Chinese law. Assume that the company unequivocally violated rules that legal officials unanimously recognize as law and that Chinese courts have repeatedly applied. But assume further that any sanctions would be crippling for the company, undermining China's long-term industrial strategy. As a student of Chinese law, I predict that a Chinese court would rule for the company; the levers of Party-state influence would ensure such an outcome.310 But should an American court give effect to this prediction?

308 See Guimei v. Gen. Elec. Co., 91 Cal. Rptr. 3d 178, 187-88 (Ct. App. 2009) (crediting expert opinion that focused on both the availability of certain procedural rights on paper and on the operation of courts in practice).

309 This is not to suggest that functionalist approaches are always accurate. Our subjective biases can shape how we filter and emphasize foreign legal information, even if our attention is to function rather than form. See William P. Alford, On the Limits of Grand Theory in Comparative Law, 61 WASH. L. REV. 945, 946, 955-56 (1986).

310 See WANG, supra note 148 , at 64-85 (describing how cases of important social impact are not often dealt with through application of formal law, but instead through broader considerations of social interests, often through "adjudication committees" within courts or local party committees that supervise judicial work). In fact the Chinese government would not likely bring such a case to begin with, but let's ignore that for the sake of the hypothetical. 
The short answer is no. Literal predictions of this sort would violate basic positivist intuitions about law. ${ }^{311}$ What constitutes law is typically a matter of social convention, of what judges and legal officials recognize the law to be.312 While a sanction-backed command from a party boss to flout law may also regulate conduct, that is not itself law, for judges and other officials would nevertheless describe such instructions as meddling with law, the opposite of law. That is why, as William Baude and Stephen Sachs point out, we often speak of the Soviet Union as lacking in the rule of law- "far too often, the law was not what ruled." 313

For this reason, the predictive rule requires an important modification. Courts should not just do as foreign courts would do; they should predict how a foreign court would rule if interpreting the law in good faith. This may have been implicit in previous formulations of the rule, but-given the authoritarian setting-it warrants being said out loud.

This formulation of the predictive rule is grounded in sound policy. When parties select a forum's law to apply, it is fair to assume they would like the law to be applied as good-faith courts would interpret it - not as varied by political instruction. ${ }^{314}$ While this could lead to some disuniformity, in the sense that an American court might reach a different conclusion on Saudi law than a Saudi court would, the alternative would do away entirely with any pretense that American courts are interpreting "law" at all.

A similar approach ought to govern how courts regard foreign judicial decisions. If the meaning of a statute is clear, but in a recent case a party committee instructed a judge to interpret it differently, an American court should not credit that case as persuasive. Admittedly, direct evidence of interference is rarely attainable. But formalist approaches would miss it entirely. Functionalist judging, on the other hand, might be a little more skeptical of sensitive cases that were sparsely reasoned or inconsistent with local methods or meanings.

Finally, formal sources of law can be necessary inputs within this functionalist brand of judging. If it is determined through a more contextual inquiry that particular kinds of formality are locally and legally authoritative,

311 See generally H.L.A. HART, THE CONCEPT OF LAW (3d ed. 2012).

312 For a sophisticated jurisprudential treatment of what happens when informal practices depart from an "official story of the law," see generally William Baude \& Stephen Sachs, The Official Story of the Law (June 9, 2020) (unpublished manuscript) (on file with author).

313 Id. at 33; see also William Baude, Is Originalism Our Law?, 115 COLUM. L. REV. 2349, 2388 (2015); Stephen Sachs, Finding Law, 107 CALIF. L. REV. 527, 565 (2019). See generally Mikolaj Barczentewicz, The Illuminati Problem and Rules of Recognition, 38 OXFORD J. LEGAL STUD. 500 (2018).

314 A more "realist" account may point out that some businesses choose certain laws or forums precisely because they can exercise extralegal influence over them. See WANG, supra note 148 , at 83 . But giving judicial effect to manipulations of this sort would be contrary to basic public policies, including notions of fairness and legality. 
formal law can help judges distinguish between what is law and what are actually efforts to subvert it.

\section{b. Formalism and Inaccuracy}

Formalism's primary weakness is that it systematically tends towards misstatements of foreign law. By underestimating the amount of distance between the foreign system and our own, formalism risks overnormalizing autocratic law. ${ }^{315}$

Formalist overnormalizing takes a variety of forms. A straightforward example, applicable to foreign law generally, is the tendency of some courts to apply local tools of statutory construction to foreign statutes. In interpreting China's Marriage Law, a court in California once asserted that since the "sole issue is one of statutory construction," it would "apply the following familiar rules to this task":316 it would "ascertain the intent to the Legislature," beginning with the "words of a statute" and "their ordinary meaning"; if the language "is clear and ambiguous," it would "go no further"; but if multiple reasonable constructions were possible, it would consult such "extrinsic aids" as the "the evils to be remedied," the "legislative history," and "public policy." 117 This programmatic approach to interpretation would be familiar to any American student of legislation. But for a Chinese judge called to interpret the same Chinese statute, a recitation of this decision tree structure would seem wholly out of place. The formal-universalist logic here is apparent: they have statutes, as do we; they must interpret those statutes as we do here. 318

Formalism's tendency to overnormalize is particularly stark in the context of autocratic law. More than once, U.S. courts have cited and analyzed the Chinese Constitution, despite its widely recognized status as something of a sham text. ${ }^{319}$

315 Considered in this way, the "antiauthoritarian biases" described in Part II can be thought of as having overforeignizing effects, causing judges to overestimate the amount of distance between foreign law and our own.

316 In re Marriage of Song \& Ye, No. Ho30253, 2007 WL 1475843, at *6 (Cal. Ct. App. May 22, 2007). Similarly, the Fourth Circuit once interpreted Pakistani law using "the canons of statutory construction with which we interpret our own laws." United States v. Mitchell, 985 F.2d 1275, 1281 (4th Cir. 1993). The case has been cited for the proposition that "in making foreign law determination[s], [a] court may draw upon the canons of statutory interpretation with which U.S. courts interpret American laws." United States v. Xu, No. 02-0674, 2008 WL 1315632, at *3 (D. Nev. Apr. 10, 2008).

317 Marriage of Song \& $Y e, 2007$ WL $1475^{843}$, at *6.

318 For a general account of this problem, see NISHITANI, supra note 8, at 31; Nicholas M. McLean, Comment, Intersystemic Statutory Interpretation in Transnational Litigation, 122 YALE L.J. 303 (2012).

319 See Keith Hand, Resolving Constitutional Disputes in Contemporary China, 7 E. ASIA L. REV. 51, 68-69 (2012) (describing official statements that the Chinese Constitution is "not a basis for litigation"); Qianfan Zhang, A Constitution Without Constitutionalism? The Paths of Constitutional Development in China, 
In one case, a federal district court enjoined removal of a Chinese citizen to China on the ground that he would be "subjected to the harshest possible treatment" for having violated, inter alia, the Chinese Constitution. ${ }^{320}$ In another case, a district court cited several provisions of the Chinese Constitution to support its conclusion that a Chinese business entity was "state-owned."321 Although neither judge directly applied the P.R.C. Constitution to the parties, both treated the document as persuasive "law" like any other, without any disclaimers or qualifiers as to its tenuous status within China's de facto legal hierarchy. 322 The courts' formalist error was to treat a document bearing formal resemblance to our own as if it functioned in broadly similar ways.

Formalism can overnormalize in the foreign law evaluation setting too. Consider Tang v. Synutra International, Inc., a case involving China's 2008 tainted milk scandal. 323 Parents of children who had ingested melaminecontaminated milk products brought suit against the producers' parent corporation in federal court. ${ }^{2} 2$ Defendants moved to dismiss for forum non conveniens. 325 To prove the futility of litigating the case in China, the parents offered declarations from several Chinese lawyers who had tried but failed to convince local courts to process their complaints. 326 The Court nonetheless deemed China an adequate forum, 327 citing inter alia a declaration from the Supreme People's Court stating that Chinese courts "were ready to process civil lawsuits for tainted-milk cases." 328 A declaration of this nature from an American court might be credited at face value, but given the far more specific

8 INT'L J. CONST. L. 950, 952 (2010) ("China's Constitution lacks any meaningful mechanism for implementation and is left unguarded against official violations . . . .").

320 Xiao v. Reno, 837 F. Supp. 1506, 1542 (N.D. Cal. 1993).

321 Trans Chem. Ltd. v. China Nat'l Mach. Imp. \& Exp. Corp., 978 F. Supp. 266, 283-90 (S.D. Tex. 1997).

322 The P.R.C Constitution is fundamentally a socialist constitution, conceived as an "overtly authoritarian instrument[] of class power." Yash P. Ghai, Constitutions and Governance in Africa: A Prolegomenon, in LAW AND CRISIS IN THE THIRD WORLD 51, 57-60 (Sammy Adelman \& Abdul Paliwala eds., 1993). Though it is generally not regarded by the legal community as a source of applicable law, it has over time taken on certain other functions: it describes how certain organs of the state operate in relation with one another (though it largely omits the role of the Party); it memorializes certain policy priorities (though often only after elite consensus has been reached); and it conveys certain aspirational commitments of the party-state. Thus, while it is not per se problematic for a judge to reference the Chinese Constitution, doing so accurately requires stepping away from oversimplifying formalist assumptions.

323 No. 09-0088, 2010 WL 1375373 (D. Md. Mar. 29, 2010).

324 Id. at ${ }^{*} 1-2$.

325 Id. at ${ }^{*} 5-12$.

326 Id. at *6-7. One lawyer described having been summoned to a meeting in which local legal officials "demanded all attorneys to withdraw from representation on tainted-milk cases." Id. at *6.

$327 \mathrm{Id}$. at *12.

328 Id. at ${ }^{*} 9$. 
affidavits describing a different reality on the ground, the Court arguably mistook formality for truth. 329

\section{Efficiency and Cost}

When it comes to getting foreign law "right," formalism excels not in its overall accuracy, but in its heuristic-like efficiency in producing accurate enough interpretations at minimal cost. As explained, many autocracies have bifurcated legal systems. When their laws arise in American court, they tend to involve commercial matters, where formal written law is generally clear and faithfully applied. ${ }^{330}$ In such cases, it is hardly necessary for judges to conduct a textured, searching inquiry into which foreign rules are followed and to what degree, and whether such rules conform to local conceptions of "law." Formalism, then, can serve as a kind of "stopping rule" heuristic, a "simplified decision-making strategy" that enables judges to reach satisfactory rather than optimal decisions. 331 Even if formalism gets some of the nonmodernist cases wrong, it will get most other cases right. In the end, that might be good enough.

Formalism's efficiency is especially appealing in light of the costs associated with contextual inquiry. One might think of judges here as "cognitive misers," agents who are "limited in their capacity to process information and often seek shortcuts to reduce mental burdens." 332 When judges privilege function over form, they must forgo formalism's "simplifying" advantages and impose on themselves greater temporal and cognitive burdens. 333 Such burdens are particularly onerous for the docket-constrained frontline judges who are most often tasked with interpreting foreign laws.

Functionalist inquiries also require the use of foreign law experts. Though experts may be better attuned to the omissions, assumptions, and norms that

329 The Court also considered the availability of nonlegal remedies, such as a state compensation fund. Id. at ${ }^{*} 10-11$.

330 See supra subsection II.B.3.

331 Russell B. Korobkin \& Thomas S. Ulen, Law and Behaviorial Science: Removing the Rationality Assumption from Law and Economics, 88 CALIF. L. REV. 1051, 1077-78 (2000). In the face of complexity and constraint, "a decision not to optimize . . . might be globally 'rational."” Id. at 1078. Maggie Gardner has shown how similar heuristics explain why judges have embraced more "parochial" doctrines, given the "unfamiliarity and complexity of transnational litigation." Gardner, supra note 26, at 959-63.

332 Peter Lee, Patent Law and the Two Cultures, 120 YALE L.J. 2, 21 (201); see also Matthew Tokson, Judicial Resistance and Legal Change, 82 U. CHI. L. REV. 901, 912-16 (2015) (discussing time, effort, and cognitive decision costs involved in judicial decisionmaking).

333 See Lee, supra note 332, at 25-26 (noting that "formalism operates as a heuristic that lowers the cognitive burdens associated with lay adjudication of [highly technical and complicated] disputes"). 
underlie an unfamiliar legal system, 334 they can require significant expenditures. Experts' rates are often high and their contextual inquiries can complicate a simpler formalist story. 335 In some cases, experts might even take more extreme positions in court than they would in an academic paper, producing more confusion than clarity for a deciding judge. ${ }^{336}$

\section{Expressivity and Comity}

Finally, there are communicative externalities associated with the choice of method. Formalism may appeal to those wishing to convey certain ideas about legal legitimacy, while functionalism's relativism may better accord with norms of judicial comity.

Formalism enables American judges to express their fidelity to core concepts of law. By presuming modernist correspondences even when they do not exist, judges signal that "law" must satisfy certain minimal but universal principles. They are thus attentive to the "expressive function of law," which Cass Sunstein defines as "the function of law in 'making statements' as opposed to controlling behavior directly." 337 Judges may intend such expression to shape norms or understandings about law, either at home or in autocratic countries, or they may see formalism as an integrity-enhancing way of expressing their own commitment to the "rule of law." 338 In contrast, some functionalisms might be assailed for being too flexible about legality.339

But formalism can have expressive shortcomings too. When judges refuse to credit as "law" rules that don't resemble modernist structures, they may be accused of failing to extend appropriate comity to other nations. ${ }^{340}$ Such thinking underlay Judge Brown's assertion that a refusal to credit unwritten laws would be "unduly condescending toward foreign legal regimes structured

334 See Bodum USA Inc. v. La Cafetière, Inc., 621 F.3d 624, 638-39 (7th Cir. 2010) (Wood, J., concurring) ("There will be many times when testimony from an acknowledged expert in foreign law will be helpful, or even necessary.").

335 See Wilson, supra note 8, at 909 (describing expert testimony as an "expensive proposition").

336 See id. at 909-10 (discussing the temptation of experts hired by parties in a suit to "conceal doubts, overstate the strong, and downplay the weak aspects of the case"). But see Miner, supra note 8 , at 588 (stressing the ability of judges to determine the reliability of foreign expert testimony).

337 Cass R. Sunstein, On the Expressive Function of Law, 144 U. PA. L. REV. 2021, 2024 (1996).

$338 C f$. id. at 2025-28 (discussing consequentialist and nonconsequentialist understandings of expressivity).

339 Formalism can thus be thought of as a compromise between Slaughter's view that judges should treat illiberal law as nonlaw, and what one might caricature as a free-wheeling functionalism, which might recognize a plant or a rosebud as law.

340 In the conflicts context, which is traditionally sourced in comity principles, applying foreign law in a U.S. court can be viewed as a kind of prescriptive comity, a recognition "that the other nation has jurisdiction to prescribe rules for the transaction or event." William S. Dodge, International Comity in American Law, 115 COLUM. L. REV. 2071, 2099-100 (2015). Refusing to credit such rules could thus be regarded as a failure to extend appropriate comity. 
differently from the system used in the United States, Europe, or akin." 341 Modern comparative law thinkers speak similarly of the field's formalist past. Annelise Riles describes nineteenth-century comparative law as preoccupied with "an excessively narrow definition of law . . . as the edicts of legislatures or courts alone-which often led to the conclusion that those who had no such institutions had no "law." 342 But as the field progressed to a more "scientific" functionalism that gave a "new attention to 'context," the offensive typologies of the field's formalist past were discarded. ${ }^{343}$ Even today, formalist methods can sometimes carry a subtle universalism, a sense that your law must resemble ours.

Some judges may also see a probing functionalism as incompatible with the judicial role. The act of assessing the integrity or honesty of another court or sovereign's actions may implicate legitimate concerns over the separation of powers. ${ }^{344}$ In some settings, courts have indeed sought to avoid "sitting in judgment over the public acts" of other states. 345 But as Zachary Clopton points out, such judgments are common, even routine, across many other doctrinal areas, including forum non conveniens and foreign judgments recognition. 346 These doctrines "are routine and unremarkable, they protect important domestic and individual concerns, and they have not sparked international incident." ${ }^{347}$ In the end, a heightened attention to extralegal meddling is unlikely to disturb structural interests any more than the uncontroversial inquiries into judicial impartiality that occur in other evaluative contexts.

\section{Future Directions}

I have shown that autocratic law poses distinct challenges for American courts. Such challenges bring into sharper focus the complexities of foreign law interpretation generally. Indeed a court interpreting Iranian law must be mindful of not just possible departures from legal modernism, but also of issues stemming from language, translation, culture, and religion.

341 Animal Sci. Prods., Inc. v. China Nat'l Metals \& Minerals Imp. \& Exp. Corp., 702 F. Supp. $2 \mathrm{~d}$ 320, 424 n.100 (D.N.J. 2010), vacated and remanded sub nom. Animal Sci. Prods., Inc. v. China Minmetals Corp., 654 F.3d 462 (3d Cir. 2011).

342 See Riles, supra note 237, at 228.

343 Id.

344 Courts may hesitate, for example, to wonder whether certain past decisions were made under political influence.

345 Arango v. Guzman Travel Advisors Corp., 621 F.2d 1371, 1380 (5th Cir. 1980). Such doctrines include the act of state doctrine, the public law taboo, and Zschernig abstention. See Clopton, supra note 108, at 6-10.

346 See Clopton, supra note 108, at 10-25.

347 Id. at 5 . 
Of the many approaches attempted elsewhere, 348 I suggest a relatively modest solution: to expand the use of court-appointed experts. ${ }^{349}$ Most judges lack the time and capacity to conduct a fully contextual analysis of every foreign law question presented to her. Parties generally do not enlist experts unless the financial stakes are high, and, even if they do, "dueling" experts can pull judges towards one of two extremes. While courts have occasionally appointed their own foreign law experts, such practices are rare. ${ }^{350}$ Judges balk at high search and informational costs, and are generally accustomed to more "passive" models that rely on partisan experts. 351

Law schools and court administrators can facilitate judicial reference by establishing a database of foreign law experts, as Matthew Wilson has suggested, or special centers dedicated to such purposes. ${ }^{352}$ Enlisted experts might even develop norms or standards around costs, enabling lower fees in exchange for the reputational returns of being a judicially recognized expert (and also, less cynically, out of a sense of public service).353 Of course courtappointed experts may not be possible, or even useful, in every case, but a significant expansion in their use can help ameliorate some of the enduring difficulties of foreign law.

Methodologically, courts will be best served by tailoring their approach to the underlying doctrines and policies that spark their encounters with foreign law. Some triggers, including those that arise in immigration or forum non conveniens, are explicitly oriented towards how laws are implemented in practice. Formalism here could unduly prejudice the parties.

In cases where foreign law must be understood primarily as law, however, efficiency concerns make formalism an attractive first choice. But even here, judges should treat formal sources of law as something of a rebuttable presumption, the first rather than the only step in its analysis. Independent

348 Examples include: multilateral conventions for judicial assistance, as in the London Convention, the Montevideo Convention, and the Minsk Convention; bilateral treaties on access to foreign law, as between Australia and South Korea; transnational judicial partnerships as in the European Judicial Network; certification, as in U.S. federal practices with respect to state law; and consultations with comparative law institutes such as the Max Planck Institute in Hamburg. See NISHITANI, supra note 8 , at 24, 47-53.

349 Matthew Wilson has suggested this as one of a number of interesting proposals for improving accurate statements of foreign law. See Wilson, supra note 8, at 927-32.

350 See, e.g., FED. R. EVID. 706 (authorizing a court to "appoint expert witnesses of its own selection"); Institut Pasteur v. Simon, 383 F. Supp. 2d 792, 795 n.2 (E.D. Pa. 2005) (appointing French law expert); Wilson, supra note 8, at 928.

351 See Wilson, supra note 8, at 928-29.

352 Wilson, supra note 8, at 930-31.

353 Comparative scholars who complain of "marginalization" from mainstream American law may find new relevancies in their capacity to directly influence decisionmaking in federal court. See Riles, supra note 237 , at 224 (discussing how "one of the principal preoccupations of [comparative law] has become how to convince 'mainstream' legal scholars of the value of their enterprise"). 
research and expert testimony can unsettle existing assumptions, redirecting the court towards specific evidence of law as locally understand or practiced. The resulting functionalism can bring jurists closer to truth, so long as they do not stretch basic conceptions of law to the point of becoming contentless.

\section{CONCLUSION}

This Article marks an initial foray into the problems of interpreting autocratic law. It has drawn from two adjacent disciplines: political science and comparative law. The former teaches that features of authoritarian legal systems that appear "aberrational" are often rooted in coherent calculation and regime interest. The latter reflects accrued wisdom on how those steeped in the assumptions of one legal civilization can come to understand the laws of another. Both disciplines shed important light on the nature of the challenge and of our possible responses to it.

As autocratic forms of governance retrench in some places and expand in others, American courts will increasingly encounter legal forms that grind uncomfortably against preexisting concepts of law. In the face of this dissonance, jurists can either presume equivalence, however fictitious, or recognize difference, however unsettling. Neither approach optimizes on every factor, and every choice entails tradeoffs between important legal values. In a world of political difference, such choices will require considerable thinking in the years to come. 